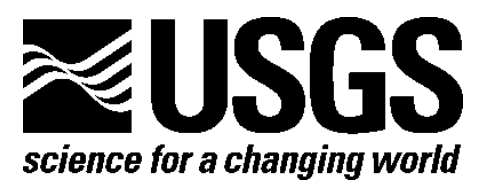

Prepared in cooperation with AMS Consultants

\title{
State-and-Transition Prototype Model of Riparian Vegetation Downstream of Glen Canyon Dam, Arizona
}

By Barbara E. Ralston, Anthony M. Starfield, Ronald S. Black, and Robert A. Van Lonkhuyzen

Open-File Report 2014-1095

U.S. Department of the Interior

U.S. Geological Survey 


\section{U.S. Department of the Interior \\ SALLY JEWELL, Secretary}

\section{U.S. Geological Survey \\ Suzette M. Kimball, Acting Director}

U.S. Geological Survey, Reston, Virginia: 2014

For more information on the USGS-the Federal source for science about the Earth,

its natural and living resources, natural hazards, and the environment-visit

http://www.usgs.gov or call 1-888-ASK-USGS

For an overview of USGS information products, including maps, imagery, and publications, visit $h$ ttp://www.usgs.gov/pubprod

To order this and other USGS information products, visit http://store.usgs.gov

Suggested citation:

Ralston, B.E., Starfield, A.M., Black, R.S., and Van Lonkhuyzen, R.A., 2014, State-and-transition prototype model of riparian vegetation downstream of Glen Canyon Dam, Arizona: U.S. Geological Survey Open-File Report 2014-1095, 26 p., http://dx.doi.org/10.3133/ofr20141095.

ISSN 2331-1258 (online)

Any use of trade, firm, or product names is for descriptive purposes only and does not imply endorsement by the U.S. Government.

Although this information product, for the most part, is in the public domain, it also may contain copyrighted materials as noted in the text. Permission to reproduce copyrighted items must be secured from the copyright owner. 


\section{Contents}

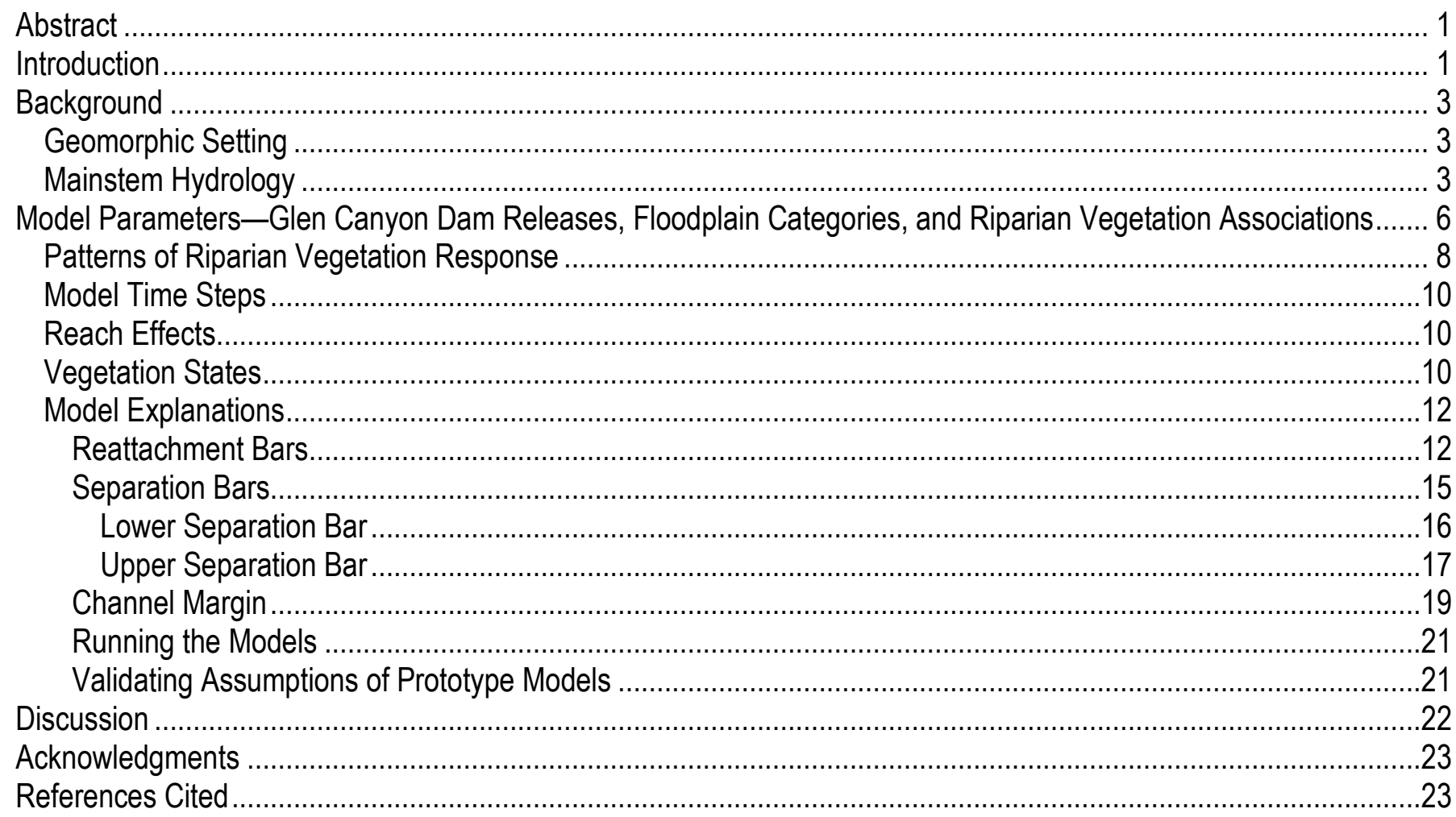

\section{Figures}

Figure 1. Map of Colorado River from Glen Canyon Dam, Arizona, to Lake Mead, Nevada, with dominant perennial tributaries identified, and the Grand Canyon National Park boundary defined. ............................... 4

Figure 2. Schematic of a debris fan/eddy complex and associated depositional features ....................................... 5

Figure 3. Example of a hydrograph showing the range of discharge ( $\left.\mathrm{ft}^{3} / \mathrm{s}\right)$ that can occur from Glen Canyon Dam measured at the Lees Ferry streamgage 09380000 for a 7-day period (November 2-9, 2013) ................................ 5

Figure 4. Hydrograph showing Colorado River discharge measured at the Lees Ferry gage from 1921 through summer 2013, with Glen Canyon Dam operations beginning in 1963.

Figure 5. Photographs showing $(A)$ a reattachment bar devoid of vegetation and a lower-angled platform, and $(B)$ a separation bar with a steeper beach face along the Colorado River in Grand Canyon National Park .......................... 9

Figure 6. State-and-transition diagram for a lower reattachment bar model. ........................................................ 13

Figure 7. State-and-transition diagram of lower separation bar model............................................................... 15

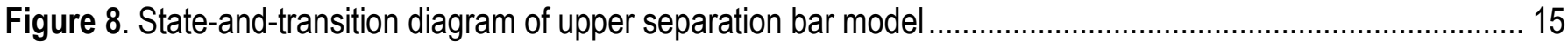

Figure 9. State-and-transition diagram of lower channel margin model .......................................................... 19

Figure 10. Screenshot of lower reattachment bar model with sustained high and low flows in the growing seasons and default operations in the nongrowing season 


\section{Tables}

Table 1. Operations of Glen Canyon Dam and extent of potential inundation for three floodplain categories (active channel, active floodplain, and inactive floodplain/uplands).

Table 2. List of community states and plant associations.

Table 3. Identification and explanation of transitions to alternative vegetation state variables for a lower reattachment bar

Table 4. Identification and explanation of transitions to alternative vegetation state variables for a lower separation bar (operations less than or equal to 31,000 cubic feet per second).

Table 5. Identification and explanation of transitions to alternative vegetation state variables for an upper separation bar.

Table 6. Identification and explanation of transitions to alternative vegetation state variables for a channel margin below discharges of 25,000 cubic feet per second

\section{Conversion Factors and Datums}

\section{Conversion Factors}

Inch/Pound to SI

\begin{tabular}{lcl}
\hline \multicolumn{1}{c}{ Multiply } & \multicolumn{1}{c}{ By } & \multicolumn{1}{c}{ To obtain } \\
\hline foot $(\mathrm{ft})$ & Length & \\
mile $(\mathrm{mi})$ & 0.3048 & meter $(\mathrm{m})$ \\
& 1.609 & kilometer $(\mathrm{km})$ \\
\hline & Flow rate & \\
\hline cubic foot per second $\left(\mathrm{ft}^{3} / \mathrm{s}\right)$ & 0.02832 & cubic meter per second $\left(\mathrm{m}^{3} / \mathrm{s}\right)$ \\
\hline
\end{tabular}

SI to Inch/Pound

\begin{tabular}{lll}
\hline \multicolumn{4}{c}{ Multiply } & By & To obtain \\
\hline meter $(\mathrm{m})$ & Length & \\
kilometer $(\mathrm{km})$ & 3.281 & foot $(\mathrm{ft})$ \\
& 0.6214 & mile $(\mathrm{mi})$ \\
\hline cubic meter per second $\left(\mathrm{m}^{3} / \mathrm{s}\right)$ & Flow rate & \\
\hline
\end{tabular}

\section{Datums}

Vertical coordinate information is referenced to the insert datum name (and abbreviation) here for instance, "North American Vertical Datum of 1988 (NAVD 88)."

Horizontal coordinate information is referenced to the insert datum name (and abbreviation) here for instance, "North American Datum of 1983 (NAD 83)."

Elevation, as used in this report, refers to distance above the vertical datum. 


\title{
State-and-Transition Prototype Model of Riparian Vegetation Downstream of Glen Canyon Dam, Arizona
}

\author{
By Barbara E. Ralston ${ }^{1}$, Anthony M. Starfield², Ronald S. Black ${ }^{3}$, and Robert A. Van Lonkhuyzen ${ }^{4}$
}

\begin{abstract}
Facing an altered riparian plant community dominated by nonnative species, resource managers are increasingly interested in understanding how to manage and promote healthy riparian habitats in which native species dominate. For regulated rivers, managing flows is one tool resource managers consider to achieve these goals. Among many factors that can influence riparian community composition, hydrology is a primary forcing variable. Frame-based models, used successfully in grassland systems, provide an opportunity for stakeholders concerned with riparian systems to evaluate potential riparian vegetation responses to alternative flows. Frame-based, state-and-transition models of riparian vegetation for reattachment bars, separation bars, and the channel margin found on the Colorado River downstream of Glen Canyon Dam were constructed using information from the literature. Frame-based models can be simple spreadsheet models (created in Microsoft ${ }^{\circledR}$ Excel) or developed further with programming languages (for example, C-sharp). The models described here include seven community states and five dam operations that cause transitions between states. Each model divides operations into growing (April-September) and non-growing seasons (October-March) and incorporates upper and lower bar models, using stage elevation as a division. The inputs (operations) can be used by stakeholders to evaluate flows that may promote dynamic riparian vegetation states, or identify those flow options that may promote less desirable states (for example, Tamarisk [Tamarix sp.] temporarily flooded shrubland). This prototype model, although simple, can still elicit discussion about operational options and vegetation response.
\end{abstract}

\section{Introduction}

Managing riparian habitats is increasingly important to conservation and public land management. Riparian vegetation in the Southwestern United States provides critical habitat and supports higher levels of biodiversity compared to upland habitats (Knopf and others, 1988). Many riparian habitats in this same region are associated with river regulation (Shafroth and others, 2002). The demands for water in this region continue to increase because of increasing population growth, potential energy development, and the greater likelihood of sustained droughts related to climate change (Seager and others, 2007). The resulting hydrology associated with climate change may include reduced snowpack and associated reduced annual volumes, earlier and shorter duration spring runoff, and less predictable summer and autumn precipitation. For regulated river systems, those changes may include

\footnotetext{
${ }^{1}$ U.S. Geological Survey, Southwest Biological Science Center, Flagstaff, Ariz.

${ }^{2}$ AMS Consultants, Dallas, Tex.

${ }^{3}$ Decision and Information Sciences Division, Argonne National Laboratory, Lemont, Ill.

${ }^{4}$ Environmental Science Division, Argonne National Laboratory, Lemont, Ill.
} 
changes in reservoir storage, increased groundwater pumping, and changes in the timing and volumes of water delivery between reservoirs (Barnett and others, 2008). Each of these flow variables affects plant responses and, collectively, may direct riparian vegetation response that favors drought-tolerant and late-successional woody species with river regulation accelerating this shift among riparian plant communities (Perry and others, 2012). These changes to the riparian plant communities will likely decrease the habitat quality for wildlife and reduce animal diversity (Shafroth and others, 2010; McCluney and Sabo, 2012).

A key species affecting the riparian landscape in the Southwestern United States since its introduction in the late 20th century is tamarisk (Tamarix sp.). Tamarisk dominates many riparian habitats in the Western United States, increases soil salinity, and may affect establishment and survival of native riparian tree species (Friedman and others, 2005; Natale and others, 2010; Merritt and Shafroth, 2012). The plant affects floodplain and channel dynamics by increasing sediment deposition that results in increased stage elevation of the floodplain, and increased depth to groundwater (Allred and Schmidt, 1999; Dean and Schmidt, 2013). The resulting drier, higher elevation and disconnected floodplain habitat supports plants that are more drought tolerant (Auble and others, 2005). A long-term effect for rivers in the Southwest may be simplification of channels, narrowing of the area occupied by riparian vegetation, and simplification of the same community.

Although multiple factors influence shifts in community composition, hydrology is a primary forcing variable affecting riparian community structure. Reductions in base flow volume narrows the area available to obligate riparian vegetation and changes inundation frequencies of shoreline habitat (Stromberg, 1993; Stevens and others, 1995; Auble and others, 2005). Large magnitude floods that remove vegetation can reset the riparian communities (Malanson, 1993; Naiman and others, 2005), while small magnitude floods may result in burial and recovery of the same plants, or recruitment of less desirable species (for example, tamarisk) depending on flood timing (Cooper and others, 2003). Facing an altered riparian plant community dominated by nonnative species, resource managers are increasingly interested in understanding how to manage and promote healthy riparian habitats in which native species dominate. For regulated rivers, managing flows is one tool resource managers consider to achieve these goals. Hydrologic changes that promote the recruitment of desirable plant species and reduce conditions that promote exotic species establishment are required (Bunn and Arthington, 2002; Poff and others, 2007).

Frame-based models provide an opportunity to evaluate knowledge of system response to disturbance or other events that may cause shifts in ecological states (Starfield, 1990). Models can be qualitative or quantitative. The construction of the frame-based models incorporates explicitly defined variables that elicit changes in ecological states. A frame-based modeling approach has proven to be useful for grassland ecosystems (Hahn and others, 1999) and has more recently been applied to riparian systems (Wondzell and others, 2007; Zweig and Kitchens, 2009). We developed a prototype framebased state-and-transition model for riparian vegetation found along the Colorado River downstream of Glen Canyon Dam. There are models for three geomorphic features: reattachment bars, separation bars, and the channel margin. Vegetation above stage elevations of $31,000 \mathrm{ft}^{3} / \mathrm{s}$ behaves similarly across geomorphic features, and a single upper separation bar model is used for all vegetation responses in this case. Because the pattern of discharge from Glen Canyon Dam is the greatest factor affecting changes in riparian vegetation, we used historical and current (2014) dam operations as the variable initiating transitions among community states to validate the models. 


\section{Background}

\section{Geomorphic Setting}

The Colorado River downstream of Glen Canyon Dam is a canyon-bound river with rapids defined by debris fans associated with the 740 tributaries that intersect the main channel (fig. 1). Depositional environments along the channel are predominantly associated with debris fans - the upstream pools resulting from the debris fan's constricting flows and the downstream eddy complexes associated with the debris fan's channel constriction (Schmidt and Graf, 1990; fig. 2). The upstream pools create low velocity environments where fine-grained sediment can accumulate and form sandbars. The eddy downstream of the debris fan constriction is another low velocity environment where sediment deposits accumulate along the shoreline either at points where the water's current separates from the main channel and moves upstream along the shore, or at the reattachment point where water rejoins the downstream current (Schmidt and Graf, 1990). These depositional areas are separation bars, reattachment bars, and the debris fans, and are contained within a debris fan-eddy complex (fig. 2). The other feature where sediment deposition occurs is the channel margin, which constitutes a large portion of the river's length. Channel margins occur along the shoreline between the debris fan-eddy complexes and generally consist of talus or cliffs where sediment covers the boulders and forms sandbanks or a coarse matrix of sand, cobble, and boulders.

\section{Mainstem Hydrology}

Releases from Glen Canyon Dam vary hourly, either increasing or decreasing in a 24-hour period, for the purpose of electrical power generation (fig. 3). The channel's floodplain can be separated into three parts based on the releases from the dam. That portion of the shoreline that is subject to changes in daily operations is referred to here as the active channel. The active floodplain is that portion of the shoreline that is subject to periodic flooding of varied durations and magnitude beyond the daily inundation the active channel experiences. Both the active channel and active floodplain are greatly compressed when compared with the pre-dam channel (fig. 4). Base flows prior to regulation were lower, but mean annual flood discharge prior to regulation was 60 percent higher (Topping and others, 2003). The historical floodplain, which has not received water from discharges associated from Glen Canyon Dam operations since 1983 (Fradkin, 1984), is referred to here as the inactive floodplain. 


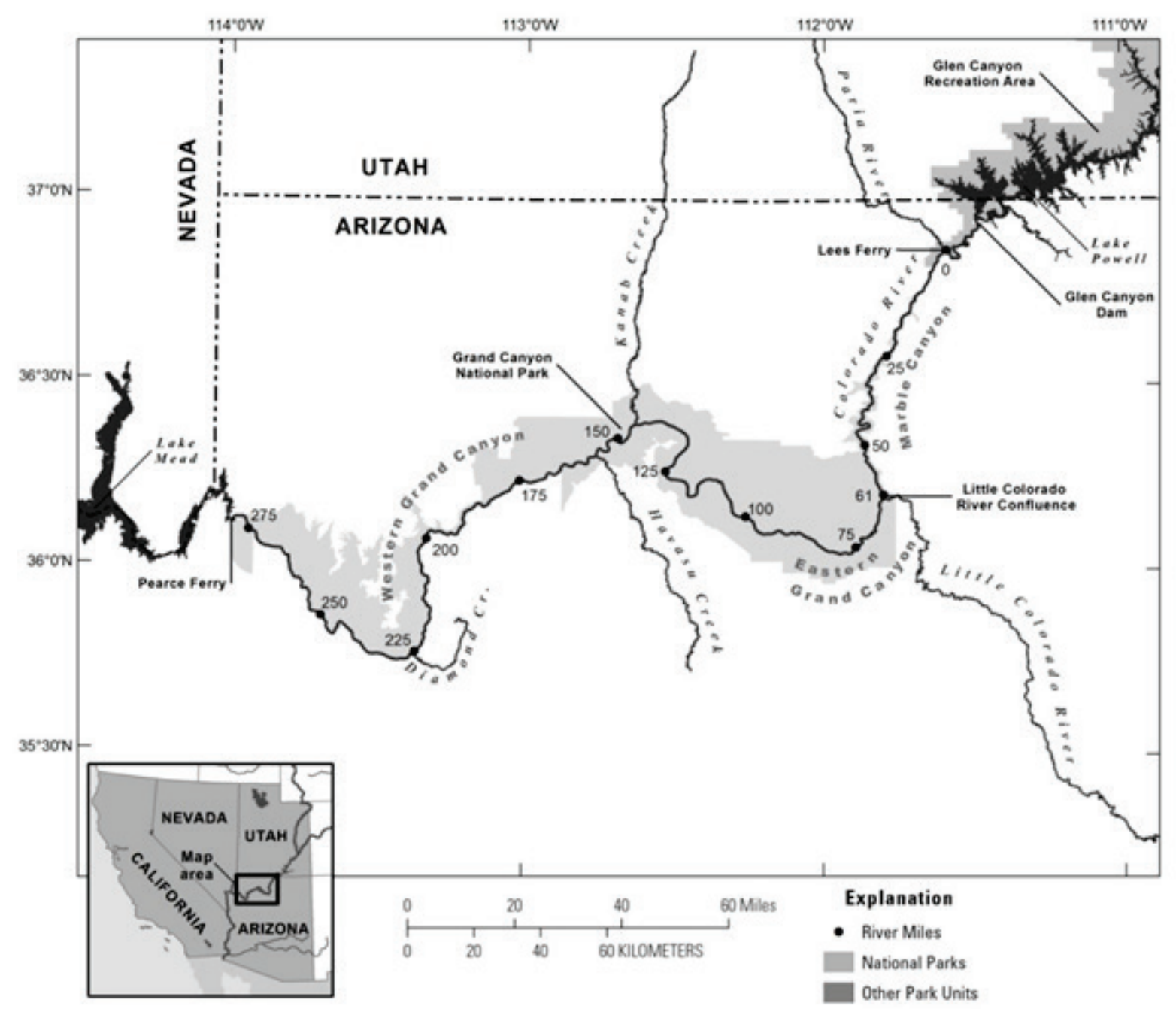

Figure 1. Map of Colorado River from Glen Canyon Dam, Arizona, to Lake Mead, Nevada, with dominant perennial tributaries identified, and the Grand Canyon National Park boundary defined. 


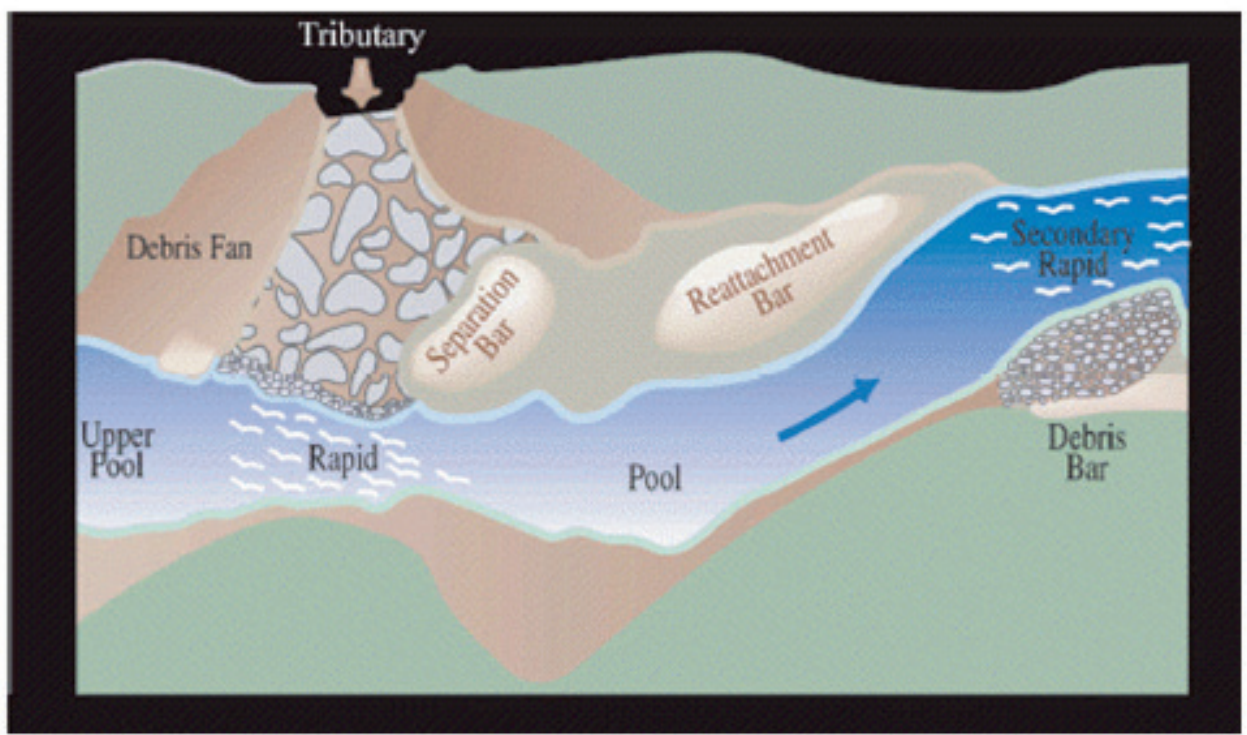

Figure 2. Schematic of a debris fan/eddy complex and associated depositional features (adapted from Webb and Griffith, 2001).

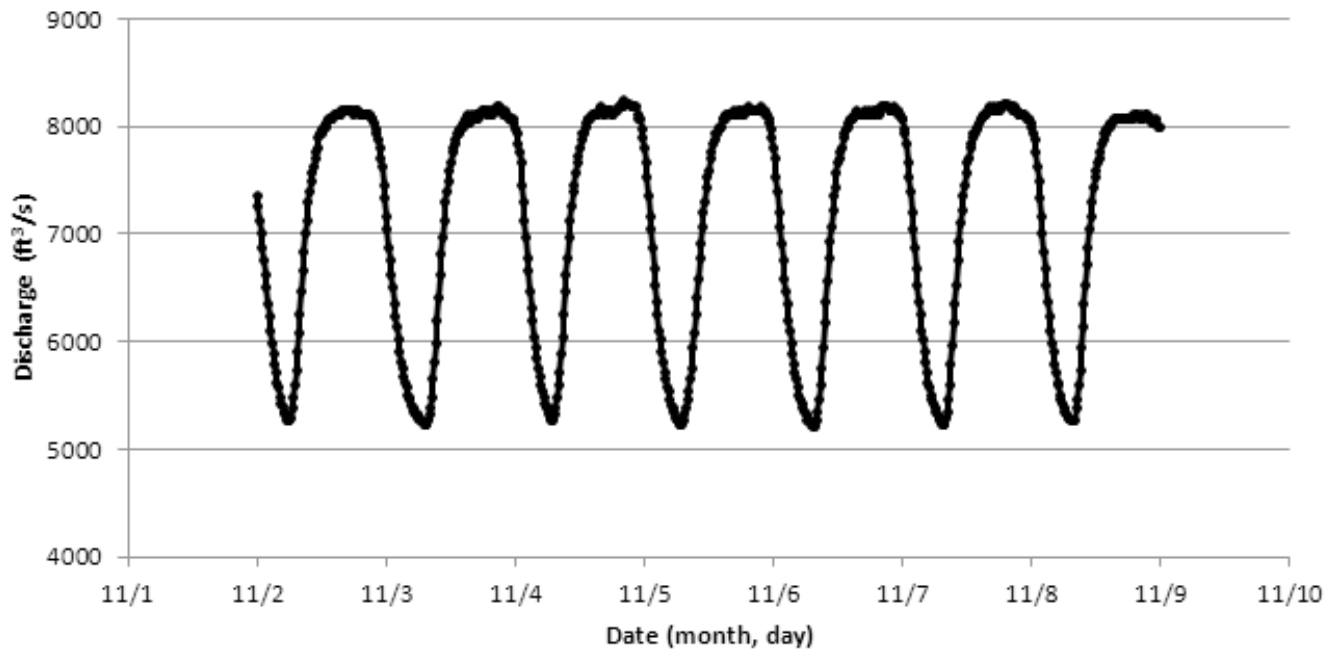

Figure 3. Example of a hydrograph showing the range of discharge $\left(\mathrm{ft}^{3} / \mathrm{s}\right)$ that can occur from Glen Canyon Dam measured at the Lees Ferry streamgage 09380000 for a 7-day period (November 2-9, 2013). The daily range of fluctuations generally is highest in the summer months (June-August). 


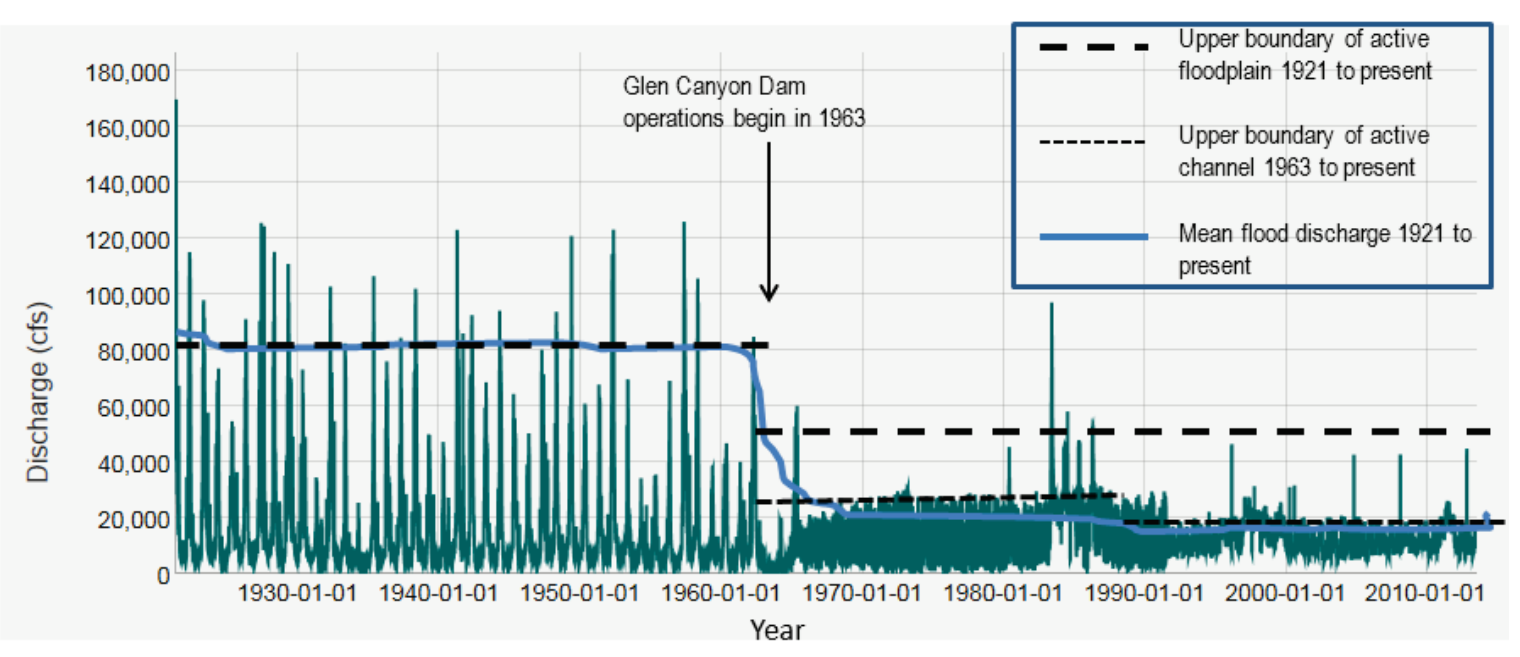

Figure 4. Hydrograph showing Colorado River discharge measured at the Lees Ferry gage from 1921 through summer 2013, with Glen Canyon Dam operations beginning in 1963. The solid blue line provides an approximate mean flood discharge for pre- and post-dam operations. The thick dashed line illustrates the upper boundary of the active floodplain prior to and following regulation. The smaller dashed line that parallels the mean flood discharge post-dam is the upper boundary of the active channel since regulation. Note that the upper boundary of the active channel was reduced to approximately 25,000 ft3/s following the initiation of interim flows in 1991.

\section{Model Parameters-Glen Canyon Dam Releases, Floodplain Categories, and Riparian Vegetation Associations}

The timing, duration, and magnitude of a river or stream's hydrology affects riparian vegetation responses (Naiman and others, 2005; Merritt and others, 2010). The Record of Decision for Glen Canyon Dam (U.S. Department of the Interior, 1996) delineates ramping rates, the allowable change in daily volumes, and the maximum discharge below which fluctuations can occur. Each hydrologic variable affects inundation frequency and duration along the shoreline and elicits a response from riparian vegetation downstream of Glen Canyon Dam (table 1). Riparian species generally assemble along a hydrologic gradient based on physiological traits including water balance requirements. For example, Stevens and others (1995) found that cattail (Typha sp.)/reed (Phragmites australis) stands occupied channel areas that were subject to inundation 54 percent of the time, whereas horsetail (Equisetum sp.)/coyote willow (Salix exigua) stands were found in areas that were inundated approximately 18 percent of the time. The location of these plant associations on the shorelines is influenced by the local geomorphology. Tamarisk/arrowweed (Pluchea sericea) and horsetail/coyote willow were associated with drier, coarser, and less disturbed separation bar platforms, however, cattail/reed were found in low velocity environments where silty/loamy soils accumulated, such as return channels associated with reattachment bars. Hydrologic and geomorphic conditions that promote the development of wetland species, such as cattails and reed, are different from those that promote woody riparian stands (Stevens and others, 1995). Differential responses among plant species form the basis for frames within the models. 
Table 1. Operations of Glen Canyon Dam and extent of potential inundation for three floodplain categories (active channel, active floodplain, and inactive floodplain/uplands).

$\left[\mathrm{ft}^{3} / \mathrm{s}\right.$, cubic feet per second; $<$, less than; $>$, greater than; $\geq$, greater than or equal to]

\begin{tabular}{|c|c|c|c|}
\hline Dam operation options & $\begin{array}{l}\text { Active channel } \\
\left(8,000-25 \mathrm{k} \mathrm{ft}^{3} / \mathrm{s}\right)\end{array}$ & $\begin{array}{l}\text { Active floodplain } \\
\left(25,000-45,000 \mathrm{ft}^{3} / \mathrm{s}\right)\end{array}$ & $\begin{array}{c}\text { Inactive } \\
\text { floodplain/uplands } \\
\left(>45,000 \mathrm{ft}^{3} / \mathrm{s}\right)\end{array}$ \\
\hline Default operations & $\begin{array}{l}\text { Daily fluctuating operations } \\
\text { that vary up to } 8,000 \mathrm{ft}^{3} / \mathrm{s} \\
\text { daily, do not fluctuate } \\
\text { above } 25,000 \mathrm{ft}^{3} / \mathrm{s} \\
\text { discharges and do not go } \\
\text { below } 8,000 \mathrm{ft}^{3} / \mathrm{s} \text { discharge } \\
\text { during the day in Glen } \\
\text { Canyon. }\end{array}$ & No inundation & No inundation \\
\hline High-flow experiment & $\begin{array}{l}\text { Steady flows for duration of } \\
\text { operations that exceed } \\
\text { default operations. Duration } \\
\text { at peak can be up to } 168 \\
\text { hours depending on } \\
\text { sediment availability. } 100 \\
\text { percent inundation for up to } \\
168 \text { hours. }\end{array}$ & $\begin{array}{l}\text { Short duration ( }<5 \text { days) } \\
\text { High flow in spring or } \\
\text { autumn can range from } \\
25,000 \text { to } 45,000 \mathrm{ft}^{3} / \mathrm{s} \text {. } \\
\text { Inundation up to } 100 \\
\text { percent, but duration of } \\
\text { inundation at peak is } 168 \\
\text { hours. }\end{array}$ & No inundation \\
\hline Sustained high flows & $\begin{array}{l}\text { High steady flows } 20,000- \\
25,000 \mathrm{ft}^{3} / \mathrm{s} \text { of duration } \geq 1 \\
\text { month. Associated with } \\
\text { reservoir equalization } \\
\text { flows. } 100 \text { percent } \\
\text { inundation for } 1 \text { month or } \\
\text { more }\end{array}$ & $\begin{array}{l}\text { Inundation between } 25,000 \\
\text { and } 45,000 \mathrm{ft}^{3} / \mathrm{s} \text { discharges. } \\
\text { Can occur with equalization } \\
\text { flows } \geq 25,000 \mathrm{ft}^{3} / \mathrm{s} \text {. } \\
\text { Duration of inundation is } \\
\text { greater than } 96 \text { hours and } \\
\text { inundation at a steady } \\
\text { discharge (that is, flat } \\
\text { hydrograph) }\end{array}$ & No inundation \\
\hline Sustained low flows & $\begin{array}{l}\text { Low steady flows } \leq 10,000 \\
\mathrm{ft}^{3} / \mathrm{s} \text {. Duration for } \\
1-3 \text { months }\end{array}$ & No inundation & No inundation \\
\hline Spill control flooding & $\begin{array}{l}\text { Steady flows for the } \\
\text { duration of the high flow }\end{array}$ & $\begin{array}{l}\text { High magnitude flow in late } \\
\text { spring/summer }>45,000 \\
\mathrm{ft}^{3} / \mathrm{s} \text {. Historically these } \\
\text { flows completely inundated } \\
\text { the active floodplain. }\end{array}$ & $\begin{array}{l}\text { Inundation to } 90,000 \\
\mathrm{ft}^{3} / \mathrm{s} \text { discharge } \\
\text { possible }\end{array}$ \\
\hline
\end{tabular}


Operational rules for Glen Canyon Dam define upper and lower bounds of daily inundation that encompasses the active channel and the stage elevations along the channel where shorelines are inundated occasionally, delineating the active floodplain. Since 1991, fluctuations have been restricted to dam releases less than or equal to $25,000 \mathrm{ft}^{3} / \mathrm{s}$, and this defines the active channel. For the purposes of this model, flooding under river regulation generally is any dam release greater than $25,000 \mathrm{ft}^{3} / \mathrm{s}$. By operational rule, dam releases greater than $25,000 \mathrm{ft}^{3} / \mathrm{s}$ must be steady releases and generally are associated with a short-duration high flow or with equalization of Lake Powell and Lake Mead Reservoirs. The active floodplain in this model is associated with stage elevations above $25,000 \mathrm{ft}^{3} / \mathrm{s}$. Maximum releases from Glen Canyon Dam since 1991 have been 45,000 $\mathrm{ft}^{3} / \mathrm{s}$ (Melis, 2011). Operations, for the most part, have reduced frequency, magnitude, and duration of flood disturbance, except in the active channel where disturbance can occur daily. Channel slopes at elevations higher than the active floodplain (for example, stage elevations above $45,000 \mathrm{ft}^{3} / \mathrm{s}$ ) have not been flooded since 1983-1987.

\section{Patterns of Riparian Vegetation Response}

The composition of a riparian plant community is dependent on species' life history traits, hydrology, and geomorphic setting (Malanson, 1993; Stromberg, 1998; Merritt and others, 2010). Alluvial and canyon-bound channels characterize segments of the Green and Colorado Rivers in the Colorado River Basin, and geomorphic features available for riparian plant establishment consist of islands, channel margins, eddy-debris fan complexes, broad floodplain surfaces, and higher fluvial terraces (Schmidt and Graf, 1990; Grams and Schmidt, 2002). The channel characteristics (for example, meandering versus constrained) affect sediment accretion on these surfaces (Rubin and others, 1990; Allred and Schmidt, 1999) and, in combination with the duration, magnitude, and timing of flooding, affect the probability of seed germination and plant establishment. Spring floods might favor cottonwood establishment because the species produces seeds in a discrete window of time in the spring (Stromberg, 1998). In contrast, flooding that occurs in late June or July can favor tamarisk, which produces seeds throughout the late spring and summer (Stromberg, 1998; Cooper and others, 2003). Cooper and others (2003) found few cottonwoods in constrained segments of the Colorado and Green Rivers (for example, Yampa and Lodore Canyons), and most of the trees were associated with finetextured bars positioned well away from the channel and in reaches where the river widened. The predam tamarisk were associated with pooling habitat upstream of debris fans or on bars associated with eddies downstream of debris fans. 
The channel of the Colorado River in Marble and Grand Canyons is constrained by bedrock. Vegetation is largely associated with pool and eddy environments (Stevens and others, 1995). Facultative riparian species, such as mesquite (Prosopis glandulosa), desert olive (Forestiera neomexicana), tamarisk, and arrowweed, form a band of vegetation near the river's pre-dam mean annual peak flood discharge (fig. 5) that comprises the current inactive floodplain. Other desert and upland shrubs, such as saltbush (Atriplex canescens) and snakeweed (Gutierrezia sarothrae), also are found along the channel's slopes (Clover and Jotter, 1944). Obligate, pioneer riparian species, such as coyote willow, seepwillow (Baccharis salicifolia), Emory's baccharis (B. emoryi), and the facultative riparian species tamarisk, occur in the active channel and active floodplain. The degree of development of these low-elevation riparian species is dependent on the time since flooding and the magnitude of floods. For example, Mortenson and others (2012) identified that sequential decreases in annual peak discharges over time resulted in recruitment events for tamarisk at low river channel elevations. Cottonwoods and Goodding's willows (Salix gooddingii) are rare within the river corridor and are associated with reaches where the channel broadens and a large floodplain exists (Turner and Karpiscak, 1980; Mast, 1997).

For this prototype model, we developed three models: a reattachment bar, a separation bar, and the channel margin. Reattachment bars generally are lower energy environments and lower angled and broader than separation bars (figs. $5 A$ and $5 B$ ). Inundation can be partial to complete each day on reattachment bars (Grams and others, 2010).
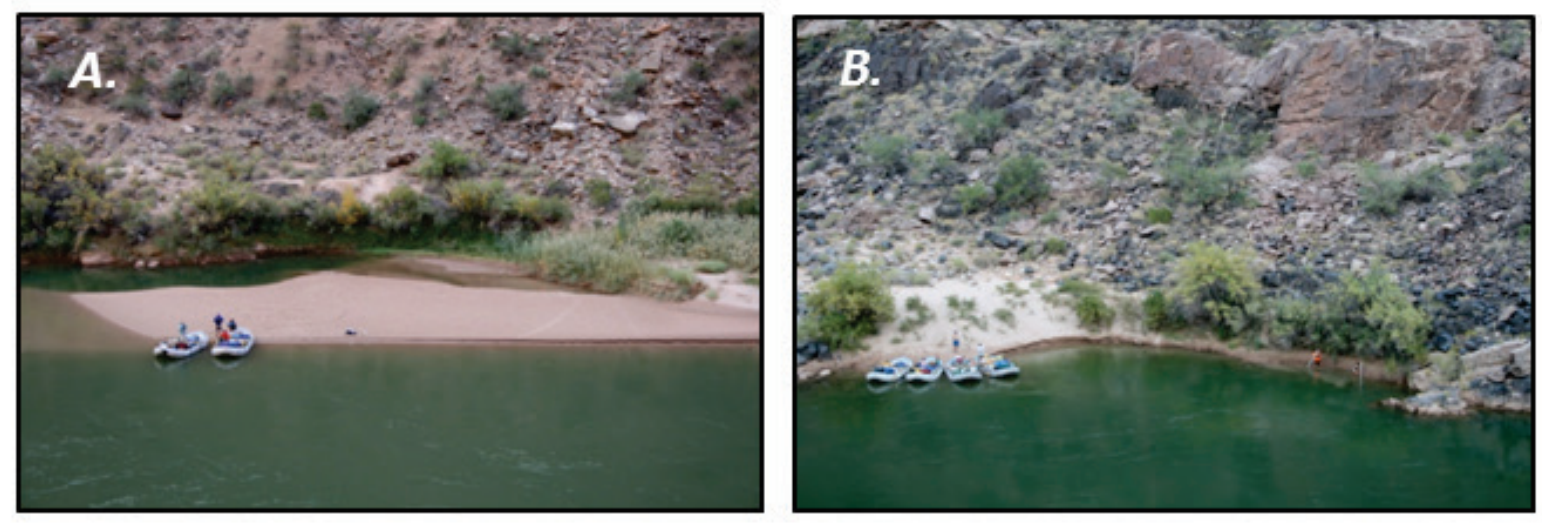

Figure 5. Photographs showing $(A)$ a reattachment bar devoid of vegetation and a lower-angled platform, and $(B)$ a separation bar with a steeper beach face along the Colorado River in Grand Canyon National Park (photograph by P. Grams, U.S. Geological Survey, taken in 2008). 


\section{Model Time Steps}

Each model divides operations into growing (April-September) and non-growing seasons (October-March). October is the beginning of the annual water year and the beginning of plant dormancy along the river. We considered more dissected time steps, but the intent of the model was to identify the simplest operational scenarios and to obtain a reasonable status of vegetation at the end of each growing season in order to assess vegetation change. In the context of the model, the plant response is applied to a group of species that may respond similarly to a series of flows and change is measured in cover. The division of operations into growing and non-growing seasons appeared sufficient to identify the likely transitions between vegetation states.

\section{Reach Effects}

Because of the difference in inundation duration among reaches associated with elevation differences, the model identifies narrow and wide reaches to calibrate the model up to 1984 . Transitions to alternative vegetation states are slower in narrow reaches. However, following the 1984 flood, the rate of change became similar across reaches (Stevens and others, 1995) and differences between reaches were removed. Changes in vegetation response may be a result of changes in grain size following the extended floods in the mid-1980s in which finer grained pre-dam sandbar deposits were exported and substrate grain sizes became homogenized across geomorphic features (Topping and others, 2000; Schmidt and Grams, 2011).

\section{Vegetation States}

We generalized vegetation occurring on a geomorphic feature into seven states (table 2). The vegetation states are essentially those vegetation associations that have been identified through community analysis and that appear in the literature (Stevens and others, 1995) or are recognized by the U.S. National Vegetation Classification (2014). We also identified a bare sand state that represents a sandbar or channel margin that is largely devoid of vegetation $(<1$ percent cover). The analysis of Stevens and others (1995) describes the states commonly found in the active channel and in low elevations in the active floodplain in all three models. The states include pioneer (for example, tamarisk) and later-stage successional plant associations that commonly occur within the river corridor. Arrowweed was combined with tamarisk as a single community association in Stevens and others (1995). These species may occupy similar stage elevations with tamarisk, but they respond differently to flows. Arrowweed is most commonly found in monotypic stands rather than intermixed with other vegetation. The most recent community analysis lumps arrowweed with seepwillow and coyote willow (NatureServe, 2012). Although arrowweed, seepwillow, and coyote willow are combined in a single plant association, there is often a spatial separation among these species where arrowweed is more commonly found at higher elevations within the active floodplain than either seepwillow or coyote willow. In the prototype model, we identified arrowweed as a separate state because of its monotypic characteristic and because it is a species of concern for stakeholders. Other states are shown in table 2. Criteria for switching are based on the percent cover of vegetation within a state. The possible operational scenarios and the sequence and frequency of their occurrence result in transitions to alternative vegetation states. 
Table 2. List of community states and plant associations.

[ $\mathrm{ft}^{3} / \mathrm{s}$, cubic feet per second; $<$, less than $; \geq$, greater than]

\begin{tabular}{|c|c|c|}
\hline Community states & Plant associations & $\begin{array}{c}\text { Channel } \\
\text { association }\end{array}$ \\
\hline S1 - Bare sand & $\begin{array}{l}<1 \text { percent vegetation. Transitions out of this state occur when } \\
\text { vegetation cover reaches } 20 \text { percent. }\end{array}$ & All \\
\hline $\begin{array}{l}\mathbf{S 2} \text { - Phragmites australis } \\
\text { temperate herbaceous vegetation }\end{array}$ & $\begin{array}{l}\text { Common reed (Phragmites australis), cattail (Typha latifolia), } \\
\text { common tule (Schoenoplectus acutus), creeping bent grass } \\
\text { (Agrostis stolonifera). Cover to } 20 \text { percent. }\end{array}$ & Active channel \\
\hline $\begin{array}{l}\text { S3 - Salix exigua-Baccharis } \\
\text { emoryi shrubland /Equisetum } \\
\text { laevigatum herbaceous }\end{array}$ & $\begin{array}{l}\text { Baccharis emoryi forms dense shrub thickets in association with } \\
\text { Salix exigua. The herbaceous layer is low to moderate in cover } \\
\text { and dominated by Schoenoplectus pungens (= Scirpus pungens). } \\
\text { Other wetland indicators that may be present include Eleocharis } \\
\text { palustris, Muhlenbergia asperifolia, and Equisetum laevigatum. } \\
\text { This state is subject to more frequent inundation than state S5, } \\
\text { which may have similar constituents. }\end{array}$ & $\begin{array}{l}\text { Active channel to } \\
\text { lower boundary } \\
\text { of active } \\
\text { floodplain } \\
\left(<31,000 \mathrm{ft}^{3} / \mathrm{s}\right. \\
\text { discharge })\end{array}$ \\
\hline $\begin{array}{l}\text { S4 - Tamarisk temporarily } \\
\text { flooded shrubland }\end{array}$ & Tamarisk (Tamarix sp.). Dense woody cover. & $\begin{array}{l}\text { Active channel } \\
\text { and throughout } \\
\text { active floodplain }\end{array}$ \\
\hline $\begin{array}{l}\text { S5 - Populus fremontii/Salix } \\
\text { exigua forest }\end{array}$ & $\begin{array}{l}\text { Stands are found on stable bars at mid-elevations of the } \\
\text { floodplain. Periodic flooding is required for the growth, } \\
\text { maintenance, and reproduction of this forest. Salix exigua in the } \\
\text { tall-shrub layer. Salix gooddingii or Baccharis salicifolia are not } \\
\text { abundant or are absent. Other associated species include } \\
\text { Distichlis spicata, Muhlenbergia asperifolia, Phragmites } \\
\text { australis, and species of Equisetum, Juncus, and Carex. } \\
\text { Introduced species, such as Elaeagnus angustifolia, Tamarix sp., } \\
\text { Poa pratensis, Melilotus spp., and other exotic forage species, } \\
\text { are often present in disturbed stands. Note: In this model, } \\
\text { Populus is rare. }\end{array}$ & $\begin{array}{l}\text { Active channel, } \\
\text { to } 31,000 \mathrm{ft}^{3} / \mathrm{s}- \\
\text { active floodplain }\end{array}$ \\
\hline $\begin{array}{l}\text { S6 - Pluchea sericea seasonally } \\
\text { flooded shrubland }\end{array}$ & $\begin{array}{l}\text { Arrowweed (Pluchea sericea) in pure stands, or associated with } \\
\text { Baccharis spp., Mesquite (Prosopis glandulosa), coyote willow. } \\
\text { The latter species occurring in low cover. }\end{array}$ & $\begin{array}{l}\text { Throughout } \\
\text { active floodplain }\end{array}$ \\
\hline $\begin{array}{l}\text { S7 - Prosopis glandulosa var. } \\
\text { torreyana shrubland }\end{array}$ & $\begin{array}{l}\text { Mesquite dominant associated with Baccharis spp., Pluchea } \\
\text { sericea. }\end{array}$ & $\begin{array}{l}\text { Primarily } \geq \\
40,000 \mathrm{ft}^{3} / \mathrm{s} \\
\text { discharge. Found } \\
\text { in inactive } \\
\text { floodplain } \\
\geq 50,000 \mathrm{ft}^{3} / \mathrm{s}\end{array}$ \\
\hline
\end{tabular}




\section{Model Explanations}

Models describe vegetation dynamics on the upper and lower portions of a geomorphic feature (for example, a reattachment bar or channel margin). The transition descriptions for alternative vegetation states that can occur on geomorphic surface are provided in tables 3-6 and figures 6-9. These transition descriptions can be used to construct user interfaces that can be simple spreadsheet models or more sophisticated models that use advanced programming languages. Initially, spreadsheet models (created in Microsoft ${ }^{\circledR}$ Excel) were created for the reattachment and separation bars that include seven states (frames) and five operations that cause transitions between states. These spreadsheets are included as examples. Subsequent model development used the $\mathrm{C}$ sharp programming language to develop the channel margin model and to improve the user interface.

\section{Reattachment Bars}

Here the lower reattachment bar model is described. The model for the upper reattachment bar and upper separation bar are identical and is described immediately following the explanation for the lower separation bar. Five states and nine transitions were identified for the lower reattachment bar (fig. 6, table 3):

- S1 Bare sand

- $\quad$ S2 Phragmites australis temperate herbaceous vegetation

- S3 Salix exigua-Baccharis emoryi shrubland/Equisetum laevigatum herbaceous vegetation

- $\quad$ S4 Tamarisk (Tamarix sp.) temporarily flooded shrubland

- S6 Pluchea sericea (arrowweed) seasonally flooded shrubland

On the spreadsheet model, the cover increment refers to Phragmites australis temperate herbaceous vegetation and affects the time to transition to state $\mathbf{S 2}$. The default cover increment is 10 percent, but this can be changed by the user. Transition T1 involves switching from S1 Bare sand to S2 Phragmites australis (fig. 6). The switch occurs when vegetation cover reaches 20 percent. Under default operations, fluctuations vary up to $8,000 \mathrm{ft}^{3} / \mathrm{s}$ daily (table 1 ), and vegetation cover increases at a fixed rate of 10 percent in each growing season. Two consecutive growing seasons of default operation results in state $\mathbf{S 1}$ switching to state $\mathbf{S 2}$ (fig. 6). Once the switch to state $\mathbf{S 2}$ occurs, the spreadsheet model operates on an accounting scheme rather than a percent cover threshold such that a certain number of sustained low flows or sustained high flows results in transitions to the next possible states.

Depending on subsequent dam operations, state $\mathbf{S 2}$ can follow transitions T2, T4, T5, or T9. Transitions T2 and T5 result in woody riparian states (S4 Tamarisk, or S3 Salix exigua - Baccharis emoryi shrubland). Transition T9 is associated with a switch to a vegetation association that is more drought tolerant (S6 Pluchea sericea). Transition T4 returns to state $\mathbf{S 1}$. State $\mathbf{S 4}$ is an end-point in riparian vegetation development. Transitions T3 and T6 result in state $\mathbf{S 4}$ following a growing season of sustained low flows preceded by sustained high flows. State $\mathbf{S 1}$ can switch immediately to state $\mathbf{S 4}$, under transition T7, when operations that expose the active channel (sustained low-flows, table 1) follow sustained high flows (Porter, 2002). All states are reversible to S1 (transitions T4 or T6). The differences between these transitions are the number of seasons of sustained high flows that are required to cause the switch. High-flow events do not effect changes in vegetation states because of their short duration. The operational sequences that cause transitions to alternative vegetation states is shown in table 3 . 


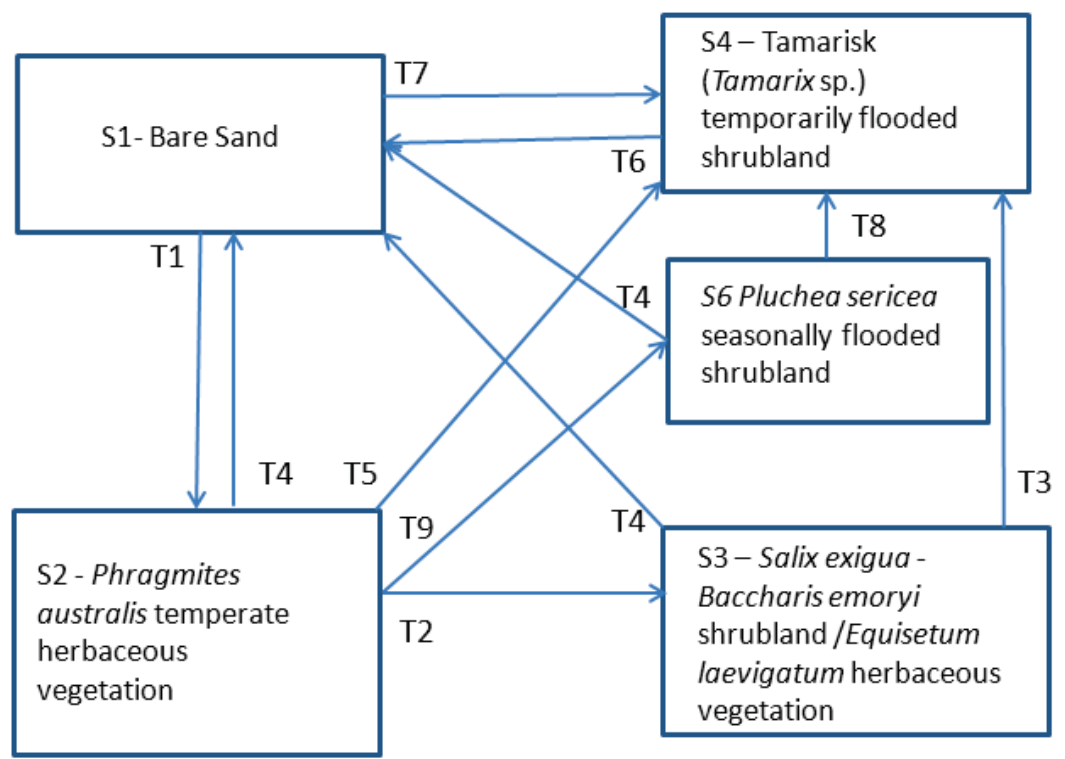

Figure 6. State-and-transition diagram for a lower reattachment bar model. Transitions are numbered and are associated with the starting state of a transition arrow pointing toward the end state.

Table 3. Identification and explanation of transitions to alternative vegetation state variables for a lower reattachment bar.

$[<$, less than $]$

\begin{tabular}{|c|c|c|c|}
\hline Transition & Vegetation states & Operations and explanation & Literature \\
\hline $\mathrm{T} 1$ & $\begin{array}{l}\text { S1 Bare sand to } \mathbf{S 2} \\
\text { Phragmites } \\
\text { australis temperate } \\
\text { herbaceous } \\
\text { vegetation }\end{array}$ & $\begin{array}{l}\text { Clonal wetland vegetation increases by } 10 \text { percent each } \\
\text { growing season under default operations. The transition } \\
\text { occurs under two consecutive growing seasons of default } \\
\text { operations, when vegetation cover reaches } 20 \text { percent. A } \\
\text { growing season sustained high flow before the switch } \\
\text { reduces cover to } 0 \text {. Bare sandbars have little seed bank } \\
\text { storage and provide a competitive advantage to clonal } \\
\text { wetland species. Default operations expand the wetted } \\
\text { perimeter and clonal wetland species can expand, upslope, } \\
\text { beyond the permanently wetted perimeter. }\end{array}$ & $\begin{array}{l}\text { Stevens and others, } \\
\text { 1995; Kearsley and } \\
\text { Ayers, 1999; } \\
\text { Ralston, } 2010\end{array}$ \\
\hline
\end{tabular}

T2 S2 Phragmites australis temperate herbaceous vegetation switch to S3 Salix exigua Baccharis spp. shrubland
Switch occurs under 4 years' consecutive seasons of default operations. Included in this is a perennial variable (1) that responds to operations. Sustained high flow will set the perennial variable back to zero. For each year of default operations, the perennial variable increases by +1 . Autumn or spring high-flow event result in a -1 . High sustained releases will drown some plants, but not all in one growing season. Low sustained releases in the nongrowing season has a similar affect as default operations. Low sustained releases in the growing season will reduce water availability, negatively affect growth of some plants, cause mortality of others and promote colonization by tamarisk (see T9).
Stevens and others, 1995 


\begin{tabular}{|c|c|c|c|}
\hline Transition & Vegetation states & Operations and explanation & Literature \\
\hline $\mathrm{T} 3$ & $\begin{array}{l}\text { S3 Salix exigua- } \\
\text { Baccharis spp. } \\
\text { shrubland switch to } \\
\text { S4 Tamarisk } \\
\text { (Tamarix sp.) } \\
\text { temporarily flooded } \\
\text { shrubland }\end{array}$ & $\begin{array}{l}\text { Switch occurs following sustained high releases in the non- } \\
\text { growing season and sustained low releases in the growing } \\
\text { seasons. Switch also can occur with sustained high releases } \\
\text { in previous year's growing season. The sustained high } \\
\text { releases reduce wetland vegetation cover to }<20 \text { percent } \\
\text { and exotic woody riparian vegetation can occupy open } \\
\text { space. }\end{array}$ & $\begin{array}{l}\text { Sher and others, } \\
\text { 2000; Mortenson } \\
\text { and others, } 2012\end{array}$ \\
\hline $\mathrm{T} 4$ & $\begin{array}{l}\mathbf{S 2}, \mathbf{S 3}, \mathbf{S 6} \text {, switch } \\
\text { to } \mathbf{S 1} \text { Bare sand }\end{array}$ & $\begin{array}{l}\text { Occurs with two consecutive seasons (growing and } \\
\text { nongrowing) of sustained high releases or two consecutive } \\
\text { growing seasons with sustained high releases. The switch } \\
\text { occurs as a result of scour of the shoreline of wetland } \\
\text { plants. One growing season is not sufficient to remove all } \\
\text { clonal vegetation. Perennial wetland vegetation does not } \\
\text { switch back S2. A spill control flood will also cause this } \\
\text { switch. }\end{array}$ & $\begin{array}{l}\text { Kearsley and Ayers, } \\
\text { 1999; Ralston, } 2010\end{array}$ \\
\hline T5 & $\begin{array}{l}\text { S2 Phragmites } \\
\text { australis temperate } \\
\text { herbaceous } \\
\text { vegetation switch to } \\
\text { S4 Tamarisk } \\
\text { (Tamarix sp.) } \\
\text { temporarily flooded } \\
\text { shrubland }\end{array}$ & $\begin{array}{l}\text { Occurs following sustained high releases in the non- } \\
\text { growing season and sustained low releases in the growing } \\
\text { seasons. Switch also can occur with sustained high releases } \\
\text { in previous year's growing season. } \\
\text { The sustained high releases reduce wetland vegetation } \\
\text { cover to }<20 \text { percent and woody riparian vegetation can } \\
\text { occupy open space. }\end{array}$ & $\begin{array}{l}\text { Sher and others, } \\
2000\end{array}$ \\
\hline T6 & $\begin{array}{l}\text { S4 Tamarisk } \\
\text { (Tamarix sp.) } \\
\text { temporarily flooded } \\
\text { shrubland switch to } \\
\text { S1 Bare Sand }\end{array}$ & $\begin{array}{l}\text { Occurs with four consecutive seasons (growing and } \\
\text { nongrowing) of sustained high releases or if four sustained } \\
\text { high releases occur in the growing season. Sustained high } \\
\text { flows result in drowning plants, and limit growth each } \\
\text { year. Successive seasons deplete energy stores and further } \\
\text { compromise plant survival. A spill control flood will also } \\
\text { cause this switch. }\end{array}$ & $\begin{array}{l}\text { Stevens and Waring, } \\
\text { 1986; Kearsley and } \\
\text { Ayers, } 1999\end{array}$ \\
\hline $\mathrm{T} 7$ & $\begin{array}{l}\text { S1 Bare sand switch } \\
\text { to } \mathbf{S 4} \text { Tamarisk } \\
\text { (Tamarix sp.) } \\
\text { temporarily flooded } \\
\text { shrubland }\end{array}$ & $\begin{array}{l}\text { Occurs under sustained low flows during one growing } \\
\text { season. Sustained low flows expose bare, wetted sandbars } \\
\text { that permit germination of tamarisk seeds, primarily. The } \\
\text { switch can occur in one growing season. }\end{array}$ & $\begin{array}{l}\text { Stevens and Waring, } \\
\text { 1986; Sher and } \\
\text { others, 2000; Porter, } \\
2002\end{array}$ \\
\hline T8 & $\begin{array}{l}\text { S6 Pluchea sericea } \\
\text { seasonally flooded } \\
\text { shrubland switch to } \\
\text { S4 Tamarisk } \\
\text { (Tamarix sp.) } \\
\text { temporarily flooded } \\
\text { shrubland }\end{array}$ & $\begin{array}{l}\text { Occurs under sustained high flows in the nongrowing } \\
\text { season followed by sustained low flows in the growing } \\
\text { season. A growing season of extended high flows followed } \\
\text { by a growing season of extended low flows also causes the } \\
\text { switch to } \mathbf{S} 4 \text { Tamarisk (Tamarix sp.) temporarily flooded } \\
\text { shrubland. The sustained high flows scour and drowned } \\
\text { vegetation and the sustained low flows expose bare, wetted } \\
\text { sandbars that permit germination of tamarisk seeds. }\end{array}$ & $\begin{array}{l}\text { Stevens and Waring, } \\
\text { 1986; Sher and } \\
\text { others, 2000; Porter, } \\
2002\end{array}$ \\
\hline T9 & $\begin{array}{l}\text { S2 Phragmites } \\
\text { australis temperate } \\
\text { herbaceous } \\
\text { vegetation switch to } \\
\text { S6 Pluchea sericea } \\
\text { seasonally flooded } \\
\text { shrubland. }\end{array}$ & $\begin{array}{l}\text { Switch occurs following one growing season of sustained } \\
\text { low flows. The component includes Equisetum sp. which } \\
\text { expands shoreward through clonal reproduction. }\end{array}$ & Porter, 2002 \\
\hline
\end{tabular}




\section{Separation Bars}

Lower and upper separation bar models (figs. 7, 8) describe vegetation dynamics on separation bars. The models appear on the same spreadsheet to facilitate comparison of responses between the two surfaces. The division in this model is the stage elevation that differentiates the active channel $(\leq 25,000$ $\left.\mathrm{ft}^{3} / \mathrm{s}\right)$ and the active floodplain $\left(\geq 25,000-45,000 \mathrm{ft}^{3} / \mathrm{s}\right)$. The upper sandbar model rarely has operations that result in a transition back to state $\mathbf{S 1}$ Bare sand (fig. 8). Operations that would cause this transition require spill control flooding with dam releases greater than $50,000 \mathrm{ft}^{3} / \mathrm{s}$ for more than 1 month (table 1). Releases such as this have only happened in the mid-1980s when Glen Canyon Dam was full and spill control operations were in effect (Fradkin, 1984). The separation bar model includes a pre-dam flood option to reset the sandbar.

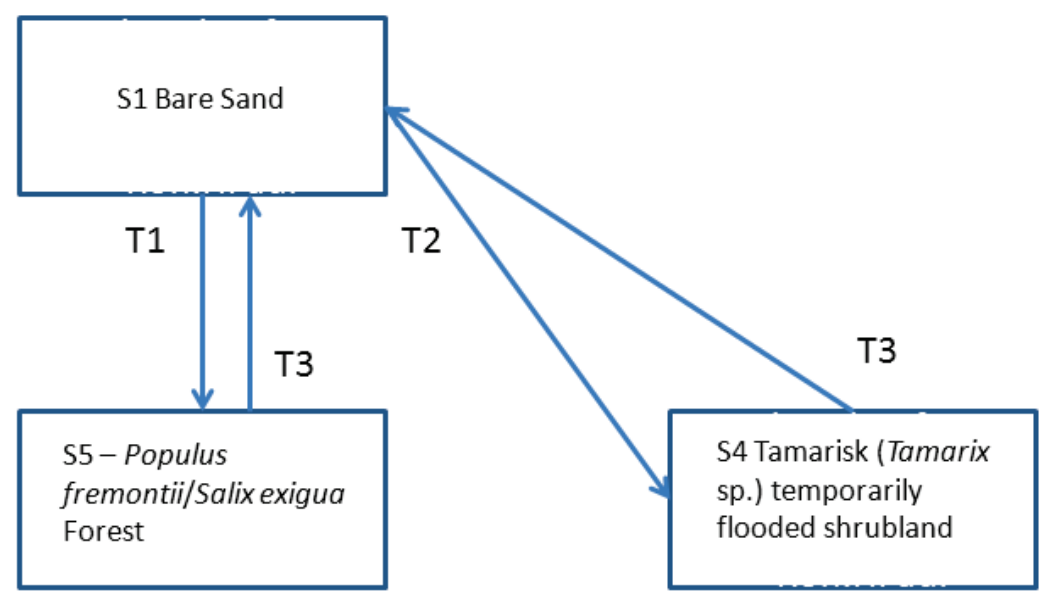

Figure 7. State-and-transition diagram of lower separation bar model. Transitions are numbered and numbers are associated with the starting state of a transition arrow pointing toward the end state.

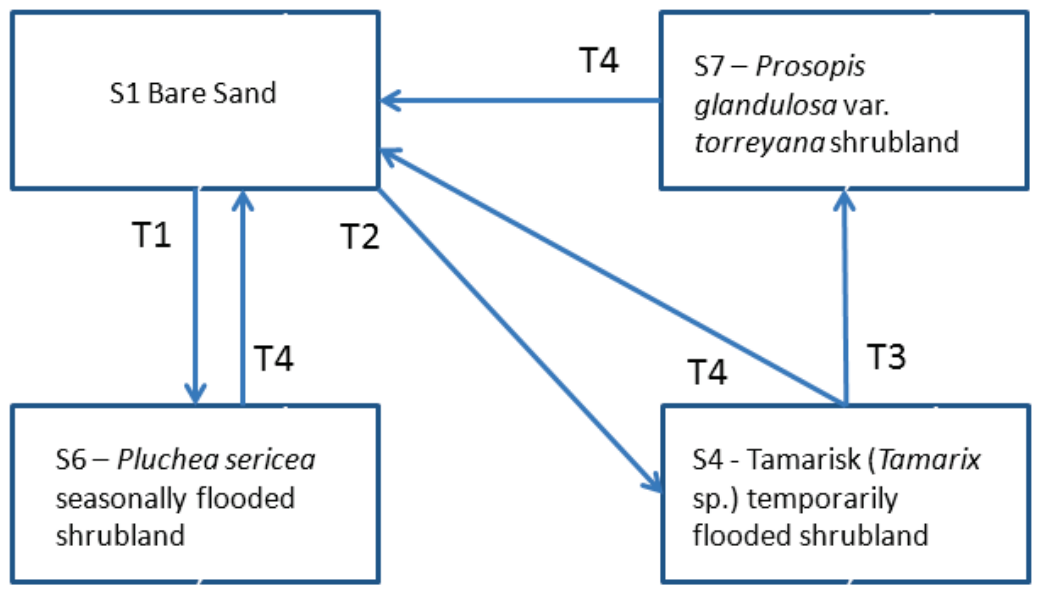

Figure 8. State-and-transition diagram of upper separation bar model. Transitions are numbered and numbers are associated with the starting state of a transition arrow pointing toward the end state. 


\section{Lower Separation Bar}

The lower separation bar is below stage elevations of $25,000 \mathrm{ft}^{3} / \mathrm{s}$ and includes the active channel. There are potentially three states and three transitions for the lower separation bar model (fig. 7). Because separation bars are higher velocity environments, state $\mathbf{S 2}$ Phragmites australis temperate herbaceous vegetation (table 2) does not occur in this model. The coarse substrate that accumulates on separation bars reduces species richness and limits vegetation states that can persist. The three states include:

- S1 Bare sand

- $\quad$ S4 Tamarisk (Tamarix sp.) temporarily flooded shrubland

- S5 Populus fremontii/Salix exigua forest

The prevalence of woody vegetation in this model results in a longer response time of vegetation to operations. Operations primarily affect the rate of vegetation cover change. Transitions between states are associated with multiple years of operations with a 20 percent cover value as a threshold for changing from one state to another, although this expansion rate can be changed by the user. Under default operations (table 1), we assumed a 3 percent cover expansion of $\mathbf{S 5}$ Populus fremontii/Salix exigua forest. At a 3 percent expansion rate, the switch from state S1 to state S5 (transition T1) occurs after 7 years of default operations (table 4). Sustained high-flow events slow the transition by reducing the percent cover by 50 percent of the previous year's value. In the spreadsheet, this value can be modified by the user. The transition T2 from state $\mathbf{S 1}$ to state $\mathbf{S 4}$ occurs when a sustained high flow in the nongrowing season is followed by an extended low flow in the growing season (table 4). Both states S5 and S4 are endpoints. Transition T3, in which either states S5 or S4 switch back to state S1, occurs when sustained high flows occur consecutively in growing and nongrowing seasons (fig. 7, table 4).

Table 4. Identification and explanation of transitions to alternative vegetation state variables for a lower separation bar (operations less than or equal to 31,000 cubic feet per second).

\begin{tabular}{|c|c|c|c|}
\hline Transition & Vegetation states & Explanation & Literature \\
\hline $\mathrm{T} 1$ & $\begin{array}{l}\text { S1 Bare Sand switch to } \\
\text { S5 Populus } \\
\text { fremontii/Salix exigua } \\
\text { forest }\end{array}$ & $\begin{array}{l}\text { Under default operations for both } \\
\text { nongrowing and growing seasons, cover } \\
\text { increases by } 3 \text { percent. Switches to } \mathbf{S 5} \text { when } \\
\text { cover reaches } 20 \text { percent. Spring high } \\
\text { sustained flows or winter high sustained } \\
\text { flows followed by summer default operations } \\
\text { decreases cover by } 50 \text { percent of previous } \\
\text { value. }\end{array}$ & $\begin{array}{l}\text { Waring, 1995; Ralston } \\
\text { and others, } 2008\end{array}$ \\
\hline $\mathrm{T} 2$ & $\begin{array}{l}\text { S1 Bare sand switch to } \mathbf{S 4} \\
\text { Tamarisk (Tamarix sp.) } \\
\text { temporarily flooded } \\
\text { shrubland }\end{array}$ & $\begin{array}{l}\text { Switches to S4 if sustained high flows in the } \\
\text { nongrowing season followed by sustained } \\
\text { low flows in the growing season. A spring } \\
\text { high flow event followed by sustained low } \\
\text { flow in the growing season will also cause } \\
\text { the switch. }\end{array}$ & $\begin{array}{l}\text { Stevens and Waring, } \\
\text { 1986; Porter, 2002; } \\
\text { Mortenson and others, } \\
2012\end{array}$ \\
\hline $\mathrm{T} 3$ & $\begin{array}{l}\text { S4, S5 switch to S1 Bare } \\
\text { sand }\end{array}$ & $\begin{array}{l}\text { Switches back to S1 Bare sand when either a } \\
\text { spill control flood or sustained high flows in } \\
\text { two consecutive seasons occur. }\end{array}$ & $\begin{array}{l}\text { Stevens and Waring, } \\
1986\end{array}$ \\
\hline
\end{tabular}


Upper Separation Bar

The upper separation bar is above stage elevations of $25,000 \mathrm{ft}^{3} / \mathrm{s}$ and vegetation responses are associated with operations that affect the active floodplain (table 1). There are potentially four states and four transitions for the upper separation bar model (fig. 8, table 5). Potential states include:

- S1 Bare sand

- S4 Tamarisk (Tamarix sp.) temporarily flooded shrubland

- S6 Pluchea sericea (arrowweed) seasonally flooded shrubland

- S7 Prosopis glandulosa var. torreyana (mesquite) shrubland

Transitions to other states from S1 Bare sand are dependent on the percent cover of arrowweed, S6 Pluchea sericea seasonally flooded shrubland, within state S1. Because sustained high flows or sustained low flow indirectly affect the upper separation bar by affecting depth to groundwater, the increase in cover either slows or accelerates in this model. The default percent increase for state $\mathbf{S 6}$ in this model was set at 5 percent per year under default operations (table 1). The rate of cover change under sustained low-flow operations also was set at 5 percent per year because operations under sustained low flows and default operations do not exceed $25,000 \mathrm{ft}^{3} / \mathrm{s}$. In contrast, operations that increase the amount of water supplied to the active floodplain increase the rate of cover change for arrowweed, state S6. For example, sustained high flows in either the growing or nongrowing seasons result in a growth rate of 7.5 percent for arrowweed for the year. Sustained high flows that occur in consecutive seasons increase the rate of cover to 10 percent. In transition T1, state S1 will switch to state $\mathbf{S 6}$ when cover reaches 30 percent (for example, 6 years under default cover change settings). The amount of arrowweed cover in state $\mathbf{S} 1$ also determines the transition T2 to state $\mathbf{S} 4$ (fig. 8). If cover is less than 10 percent and an extended high flow in the growing season combines with a spring high flow event in the same season, then the T2 transition to state $\mathbf{S 4}$ (table 5).

The third transition (T3) in which state S4 switches to state S7 Prosopis glandulosa var. torreyana (mesquite) shrubland occurs over several years of successive high-flow events and default operations. Mesquite cover starts at 0 percent in state $\mathbf{S 4}$ and adds 2 percent cover with each successive high-flow event. When cover is 25 percent, state $\mathbf{S 4}$ switches to state $\mathbf{S 7}$. Thirteen consecutive years of spring high-flow events would result in a switch from states S4 to S7. Extended low flows in the growing season reduce the rate of mesquite cover by 0.5 percent. States $\mathbf{S 6}, \mathbf{S 4}$, and $\mathbf{S} 7$ are end states.

The last transition (T4), in which all end states, S4, S6, and S7 switch back to state $\mathbf{S 1}$ occurs under the same flow operations. State $\mathbf{S} 1$ can occur in either the growing or nongrowing seasons under spill control flooding (table 1) where sustained high flows are greater than or equal to $50,000 \mathrm{ft}^{3} / \mathrm{s}$. 
Table 5. Identification and explanation of transitions to alternative vegetation state variables for an upper separation bar.

$[\leq$, less than or equal to; $>$, greater than $]$

\begin{tabular}{|c|c|c|c|}
\hline Transition & Vegetation states & Explanation & Literature \\
\hline $\mathrm{T} 1$ & $\begin{array}{l}\text { S1 Bare sand switch to } \mathbf{S 6} \\
\text { Pluchea sericea } \\
\text { (arrowweed) seasonally } \\
\text { flooded shrubland }\end{array}$ & $\begin{array}{l}\text { Input parameters allow identifying the rate of } \\
\text { increase/year of } \mathbf{S 6} \text {, arrowweed. Default } \\
\text { operations and sustained low-flow operations } \\
\text { are treated similarly with respect to the effect } \\
\text { on changes in cover. Under these operations, } \\
\text { cover increases at } 5 \text { percent per year. } \\
\text { Sustained high flows in the growing or } \\
\text { nongrowing seasons increases the cover rate } \\
\text { by an additional } 2.5 \text { percent. An autumn high- } \\
\text { flow event adds a multiplier of } 0.5 \text { to the } \\
\text { cover increase. The switch to } \mathbf{S 6} \text {, arrowweed, } \\
\text { occurs when cover reaches } 30 \text { percent. }\end{array}$ & Waring, 1995 \\
\hline $\mathrm{T} 2$ & $\begin{array}{l}\text { S1 Bare sand switch to } \mathbf{S 4} \\
\text { Tamarisk (Tamarix sp.) } \\
\text { temporarily flooded } \\
\text { shrubland }\end{array}$ & $\begin{array}{l}\text { The switch to } \mathbf{S} \mathbf{4} \text { Tamarisk occurs if the } \\
\text { percent cover of } \mathbf{S 6} \text { arrowweed in the } \mathbf{S 1} \\
\text { frame is } \leq 10 \text { percent and sustained high } \\
\text { flows in a growing season occurs following a } \\
\text { spring high-flow event. }\end{array}$ & $\begin{array}{l}\text { Sher and others, } \\
\text { 2000; Mortenson } \\
\text { and others, } 2012\end{array}$ \\
\hline $\mathrm{T} 3$ & $\begin{array}{l}\text { S4 Tamarisk (Tamarix sp.) } \\
\text { temporarily flooded } \\
\text { shrubland to } \mathbf{S 7} \text { Prosopis } \\
\text { glandulosa var. torreyana } \\
\text { (mesquite) shrubland }\end{array}$ & $\begin{array}{l}\text { The switch to } \mathbf{S} 7 \text { occurs when mesquite in the } \\
\mathbf{S} 4 \text { frame reaches } 25 \text { percent. Mesquite cover } \\
\text { increases at a rate of } 2 \text { percent for a spring } \\
\text { high-flow event plus either a growing season } \\
\text { default or sustained high flows in the growing } \\
\text { season. The percent cover of mesquite } \\
\text { decreases by } 0.5 \text { percent when there is an } \\
\text { extended low flow in the growing season. }\end{array}$ & $\begin{array}{l}\text { Anderson and } \\
\text { Ruffner, } 1987\end{array}$ \\
\hline $\mathrm{T} 4$ & $\begin{array}{l}\mathbf{S 4}, \mathbf{S 6}, \mathbf{S 7} \text { switch to } \mathbf{S 1} \\
\text { Bare sand }\end{array}$ & $\begin{array}{l}\text { Spill control floods - pre-dam or long } \\
\text { duration ( }>30 \text { days) high flows }>50,000 \mathrm{ft}^{3} / \mathrm{s} \\
\text { results in the switch back to } \mathbf{S 1} \text { from any of } \\
\text { the end states, } \mathbf{S 4}, \mathbf{S 6} \text {, or } \mathbf{S} 7 \text {. }\end{array}$ & $\begin{array}{l}\text { Stevens and } \\
\text { Waring, } 1986\end{array}$ \\
\hline
\end{tabular}




\section{Channel Margin}

The channel margin model has five states and six transitions. Only the $\mathbf{S 2}$ Phragmites australis (fig. 9) is missing in this model. The higher velocity environments and the coarser substrates associated with channel margins limits establishment of this state. The states in this model respond similarly to those in the reattachment bar and transition T3 in the upper separation bar model (figs. 6 and 8). The lower channel margin model was developed for stage elevations below $25,000 \mathrm{ft}^{3} / \mathrm{s}$. The upper portion of the channel margin behaves similarly to the upper separation bar model (fig. 8). The lower channel margin model uses an accounting system for the perennial variable that increases or decreases by a whole number $(+1)$ in response to default operations, or sustained high- or low-flow operations in the growing or nongrowing seasons (table 6). The states in this model include:

- S1 Bare sand

- S3 Salix exigua-Baccharis emoryi shrubland /Equisetum laevigatum herbaceous vegetation

- S4 Tamarisk (Tamarix sp.) temporarily flooded shrubland

- S5 Populus fremontii/Salix exigua forest

- $\quad$ S7 Prosopis glandulosa var. torreyana (mesquite) shrubland

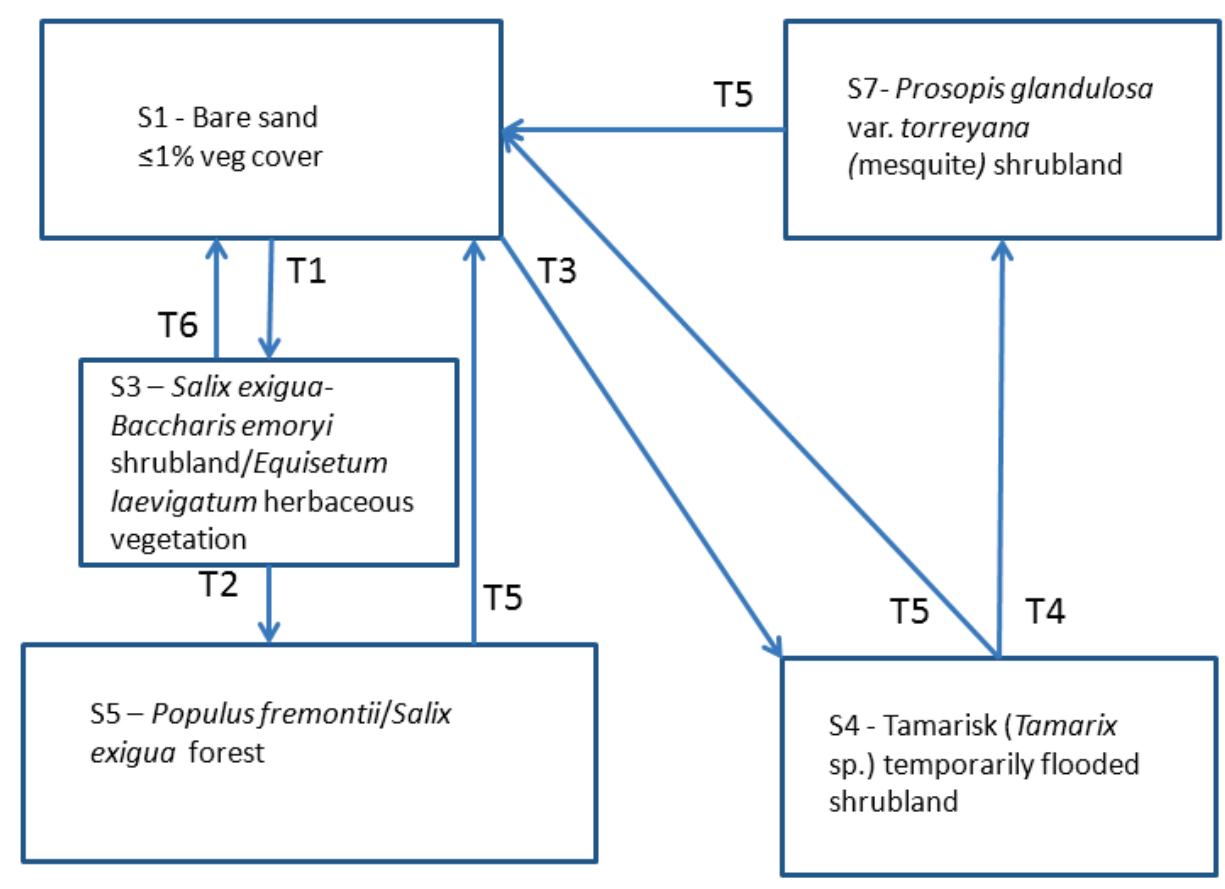

Figure 9. State-and-transition diagram of lower channel margin model. Transitions are numbered and numbers are associated with the starting state of a transition arrow pointing toward the end state. 
Table 6. Identification and explanation of transitions to alternative vegetation state variables for a channel margin below discharges of 25,000 cubic feet per second.

$[\leq$, less than or equal to; $\geq$, greater than or equal to; $>$, greater than]

\begin{tabular}{|c|c|c|c|}
\hline Transition & Vegetation state & Explanation & Literature \\
\hline T1 & $\begin{array}{l}\text { S1 Bare sand switch to } \mathbf{S 3} \\
\text { Salix exigua - Baccharis } \\
\text { emoryi shrubland / Equisetum } \\
\text { laevigatum herbaceous } \\
\text { vegetation }\end{array}$ & $\begin{array}{l}\text { For each year of default operations, the perennial variable } \\
\text { increases by }+1 \text {. When the perennial variable adds up to } \\
\text { four, the state switches to } \mathbf{S 3} \text {. The transition occurs under } \\
\text { four consecutive years of default operations. Sustained low } \\
\text { flows in the growing season and/or autumn or spring high- } \\
\text { flow event result in a }-1 \text {. Sustained low flows will reduce } \\
\text { water availability and affect growth of some plants, while } \\
\text { other plants will die from dewatering. Sustained high flow } \\
\text { in either growing or nongrowing season will set cover } \\
\text { back to zero. Sustained high flows will drown some plants, } \\
\text { but not all in one growing season. }\end{array}$ & $\begin{array}{l}\text { Stevens and } \\
\text { Waring, 1986; } \\
\text { Porter, } 2002\end{array}$ \\
\hline $\mathrm{T} 2$ & $\begin{array}{l}\text { S3 Salix exigua - Baccharis } \\
\text { emoryi shrubland /Equisetum } \\
\text { laevigatum herbaceous } \\
\text { vegetation switch to S5 } \\
\text { Populus fremontii/Salix } \\
\text { exigua forest }\end{array}$ & $\begin{array}{l}\text { Operations that increase overstory cover and decrease } \\
\text { herbaceous understory plants promote the switch. Switch } \\
\text { can occur under extended high flows in nongrowing or } \\
\text { growing seasons followed by extended low flows in the } \\
\text { subsequent growing season. The extended high flows will } \\
\text { scour herbaceous vegetation, but most woody plant may } \\
\text { remain. }\end{array}$ & Ralston, 2010 \\
\hline $\mathrm{T} 3$ & $\begin{array}{l}\text { S1 Bare sand switch to } \mathbf{S 4} \\
\text { Tamarisk (Tamarix sp.) } \\
\text { temporarily flooded } \\
\text { shrubland }\end{array}$ & $\begin{array}{l}\text { Occurs following sustained high releases in the } \\
\text { nongrowing season and sustained low releases in the } \\
\text { growing seasons. The sustained high releases perennial } \\
\text { variable to } \leq 2 \text { and tamarisk can occupy open space. }\end{array}$ & $\begin{array}{l}\text { Sher and others } \\
2000 \text {; } \\
\text { Mortenson and } \\
\text { others, } 2012\end{array}$ \\
\hline $\mathrm{T} 4$ & $\begin{array}{l}\text { S4 Tamarisk (Tamarix sp.) } \\
\text { temporarily flooded } \\
\text { shrubland switch to } \mathbf{S 7} \\
\text { Prosopis glandulosa var. } \\
\text { torreyana shrubland }\end{array}$ & $\begin{array}{l}\text { The switch to } \mathbf{S} 7 \text { occurs when mesquite in the } \mathbf{S} \mathbf{4} \text { frame } \\
\text { reaches } 25 \text { percent. Mesquite cover increases at a rate of } 2 \\
\text { percent for each spring high-flow event followed by } \\
\text { sustained high flows or default operations in the growing } \\
\text { season. The percent cover of mesquite decreases by } 0.5 \\
\text { percent whenever there is an extended low flow in the } \\
\text { growing season. }\end{array}$ & $\begin{array}{l}\text { Anderson and } \\
\text { Ruffner, } 1986\end{array}$ \\
\hline T5 & $\begin{array}{l}\text { S5 Populus fremontii/Salix } \\
\text { exigua forest, S4 Tamarisk } \\
\text { (Tamarix sp.) temporarily } \\
\text { flooded shrubland, or } \mathbf{S 7 -} \\
\text { Prosopis glandulosa var. } \\
\text { torreyana (mesquite) } \\
\text { shrubland switch to } \mathbf{S 1} \text { Bare } \\
\text { sand }\end{array}$ & $\begin{array}{l}\text { Spill control floods-pre-dam or long duration ( }>30 \text { days) } \\
\text { high flows }>50,000 \mathrm{ft}^{3} / \mathrm{s}\end{array}$ & $\begin{array}{l}\text { Stevens and } \\
\text { Waring, } 1986\end{array}$ \\
\hline T6 & $\begin{array}{l}\text { S3 Salix exigua - Baccharis } \\
\text { emoryi shrubland /Equisetum } \\
\text { laevigatum herbaceous } \\
\text { vegetation switch to S1 Bare } \\
\text { sand }\end{array}$ & $\begin{array}{l}\text { Switch occurs when extend high flows of } \geq 25,000 \mathrm{ft}^{3} / \mathrm{s} \\
(>30 \text { days })\end{array}$ & $\begin{array}{l}\text { Stevens and } \\
\text { Waring, } 1986\end{array}$ \\
\hline
\end{tabular}


The first transition (T1), which is state $\mathbf{S 1}$ switching to state $\mathbf{S 3}$, occurs when the perennial variable is equal to four. Four consecutive years of default operations in the growing and nongrowing seasons will trigger the switch from states $\mathbf{S 1}$ to S3. Transition T1 is similar to transition T2 for the reattachment bar (table 3), but $\mathbf{S 2}$ Phragmites australis does not appear as an intermediate state. Sustained low flows and autumn or spring high-flow events results in a -1 and reduction in the perennial variable. Years in which sustained high flow occurs in either a growing or nongrowing season sets the perennial variable back to zero. State $\mathbf{S 3}$ is not an end state while all other states $(\mathbf{S 4}, \mathbf{S 5}, \mathbf{S 7})$ are end states because each of these require spill control floods at greater than or equal to $50,000 \mathrm{ft}^{3} / \mathrm{s}$ to transition (T5) back to state S1 (table 6). Transition (T6) back to state S1 from state $\mathbf{S 3}$ occurs under sustained high flows of greater than or equal to $25,000 \mathrm{ft}^{3} / \mathrm{s}$ (fig. 9).

Transition T2 is the switch in states from S3 to S5. The trigger for the switch is when the perennial variable is equal to 6 . Flow combinations that can affect this change include either a sustained high flow in the nongrowing season and a sustained low flow in the growing season, or a sustained high flow in the growing season followed by sustained low flow in the growing season (table 6).

Transition T3 is dependent on the development of the perennial variable. If the perennial variable is less than or equal to 2 and sustained low flows occur in the growing season, state S1 can switch to state S4. Transition T4, which is the switch from states S4 to S7, follows the same rules as those described previously for the upper separation bar model.

\section{Running the Models}

The prototype models for the reattachment and separation bars are Microsoft ${ }^{\circledR}$ Excel spreadsheets (see attached reattachment bar and separation bar models). C sharp programming was subsequently used to construct the channel margin model and improve the user interface for the reattachment and separation bar models. For the spreadsheet models, the input area for dam operation options (table 1) is in the center of the spreadsheet. The columns are divided into growing and nongrowing season actions with operation options available under each. The output on the left side of the spreadsheet (States) indicates the vegetation state at time X. Inputs include rate of cover expansion cells that are located above dam operation options. Because high-flow events are of short duration, this operation cannot be the only operation occurring in a season. Default operations precede in the background, and the input of other flow options affect the response of vegetation. The model generally starts with bare sand, although multiple starting states could be used to simulate changes in bars that exist in different states, a more natural occurrence throughout a river channel.

\section{Validating Assumptions of Prototype Models}

The prototype model can be used to calibrate assumptions of vegetation response. For the reattachment model, we ran operations for 1963-2009 that included sustained high flows in the growing and nongrowing seasons based on the historical hydrograph for that period. In this case, default operations generally were fluctuations to power plant capacity (that is, $31,000 \mathrm{ft}^{3} / \mathrm{s}$ ) or modified low fluctuating flows, but always daily fluctuations. Because the model is not estimating area cover, the range of daily fluctuations does not need to be incorporated in such detail-the intent of the model is to identify the appropriate threshold for identifying a change in the community state. The rate of expansion when bare sand becomes clonal wetland and then perennial wetland vegetation roughly agrees with the time sequence identified for wetland development on the river by Stevens and others (1995). 


\section{Discussion}

A state-and-transition model can help identify basic organizing components and ecological drivers that effectively cause a transition from one state to another. The prototype model described here identifies the most prominent vegetation states and the dam operations that cause transitions among states associated with sandbars downstream of Glen Canyon Dam. The prototype can be used to test alternative flow options, provided the assumptions for vegetation response are correct. As an example, in the lower reattachment bar model, seasonally sustained high flows and sustained low flows (table 1) were entered periodically in the growing season for an 11-year period followed by default operations (fig. 10). The states that exist on the bar switch from state $\mathbf{S 1}$ Bare sand to state $\mathbf{S} 4$ Tamarisk, gets reset to $\mathbf{S 1}$ Bare sand, switches to $\mathbf{S 2}$ Phragmites australis, is reset to state $\mathbf{S 1}$ and then proceeds under default operations to state $\mathbf{S 2}$ and then to state $\mathbf{S 6}$ arrowweed. The inputs could be used by stakeholders to evaluate flows that may promote dynamic riparian vegetation states, or to identify those flow options that may promote less desirable states (for example, state $\mathbf{S 4}$ ). This prototype model, although simple, can still elicit discussion about operational options and vegetation response.

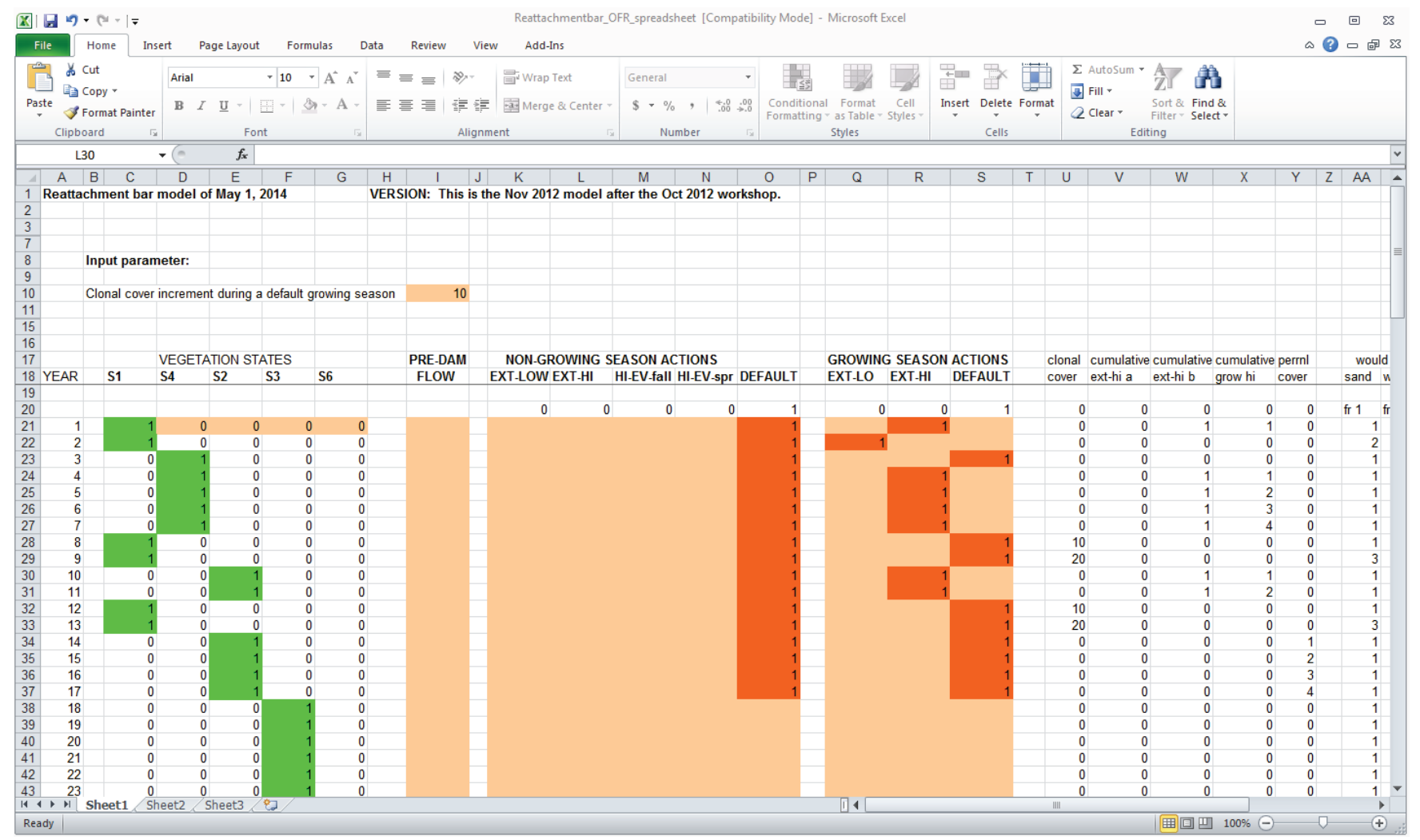

Figure 10. Screenshot of lower reattachment bar model with sustained high and low flows in the growing seasons and default operations in the nongrowing season. Under this scenario, the states switch between S1 Bare sand, S4 tamarisk, S2 Phragmites australis, and $\mathbf{S}$ Baccharis. Baccharis is projected as an end point unless sustained high flows remove the vegetation. 
Identifying the purpose of the modeling effort is required first in order to identify the amount of detail needed for a model. The user can enter other flow options to test their assumptions of vegetation response, identify expectations of vegetation response to operations that may not be possible, or reveal flaws in the prototype model that need refinement or that highlight where users may be making inappropriate assumptions. All these outcomes result in a clearer understanding of the riparian communities and the potential for dam operations to affect states that exist on channel features.

\section{Acknowledgments}

The work was funded through WaterSMART funds provided to the U.S. Geological Survey and the hydropower revenues provided by the Bureau of Reclamation as a part of the Glen Canyon Dam Adaptive Management Program. This manuscript was improved by discussion and review with Todd Chaudhry, Michael Kearsley, Lori Makarick, John Spence, and Mark E. Miller of the National Park Service.

\section{References Cited}

Allred, T.M., and Schmidt, J.C., 1999, Channel narrowing by vertical accretion along the Green River near Green River, Utah: Geological Society of America Bulletin, v. 111, no. 12, p. 1,757-1,772.

Anderson, L.S., and Ruffner, G.A., 1987, Effects of the post-Glen Canyon Dam flow regime on the old high water line plant community along the Colorado River in Grand Canyon: Salt Lake City, Utah, Glen Canyon Environmental Studies, submitted to Bureau of Reclamation, Upper Colorado Region, contract no. IA-4-AA-40-01930, technical report no. GCES/22/87, 271-286 p. [Available from National Technical Information Service, Springfield, Va., as NTIS Report PB-183504/AS.]

Auble, G., Scott, M., and Friedman, J., 2005, Use of individualistic streamflow-vegetation relations along the Fremont River, Utah, USA to assess impacts of flow alteration on wetland and riparian areas: Wetlands, v. 25, no. 1, p. 143-154.

Barnett, T.P., Pierce, D.W., Hidalgo, H.G., Bonfils, C., Santer, B.D., Das, T., Bala, G., Wood, A.W., Nozawa, T., Mirin, A.A., Cayan, D., and Dettinger, M.D., 2008, Human-induced changes in the hydrology of the western United States: Science, v. 319, no. 5866.

Bunn, S.E., and Arthington, A.H., 2002, Basic principles and ecological consequences of altered flow regimes for aquatic biodiversity: Environmental Management, v. 30, no. 4, p. 493-507.

Clover, E.U., and Jotter, L., 1944, Floristic studies in the canyon of the Colorado and tributaries: American Midland Naturalist, v. 32, no. 3, p. 591-642.

Cooper, D.J., Andersen, D.C., and Chimner, R.A., 2003, Multiple pathways for woody plant establishment on floodplains at local to regional scales: Journal of Ecology, v. 91, no. 2, p. 182-196.

Dean, D.J., and Schmidt, J.C., 2013, The geomorphic effectiveness of a large flood on the Rio Grande in the Big Bend region-Insights on geomorphic controls and post-flood geomorphic response: Geomorphology, v. 201, accessed February 11, 2014, at http://dx.doi.org/10.1016/j.geomorph.2013.06.020.

Fradkin, P.L., 1984, A river no more - the Colorado River and the west (1996, 2nd ed.): Berkeley, University of California Press, $360 \mathrm{p}$.

Friedman, J.M., Auble, G.T., Shafroth, P.B., Scott, J.M., Merigliano, M.F., Freehling, M.D., and Griffin, E.R., 2005, Dominance of non-native riparian trees in western USA: Biological Invasions, v. 7 , no. 4 , p. $747-751$. 
Grams, P.E., and Schmidt, J.C., 2002, Streamflow regulation and multi-level flood plain formationChannel narrowing on the aggrading Green River in the eastern Uinta Mountains, Colorado and Utah: Geomorphology, v. 44, no. 3-4, p. 337-60.

Grams, P.E., Schmidt, J.C., and Andersen, M.E., 2010, 2008 High-flow experiment at Glen Canyon Dam--morphologic response of eddy-deposited sandbars and associated aquatic backwater habitats along the Colorado River in Grand Canyon National Park: U.S. Geological Survey Open-File Report 2010-1032, 73 p., http://pubs.usgs.gov/of/2010/1032/.

Hahn, B.D., Richardson, F.D., and Starfield, A.M., 1999, Frame-based modelling as a method of simulating rangeland production systems in the long term: Agricultural Systems, v. 62, no. 1, p. 29-49.

Kearsley, M.J.C., and Ayers, T.J., 1999, Riparian vegetation responses-Snatching defeat from the jaws of victory and vice versa, in Webb, R.H., Schmidt, J.C., Marzolf, G.R., and Valdez, R.A., eds., The controlled flood in Grand Canyon: Washington, D.C., American Geophysical Union, Geophysical Monograph Series, v. 110, p. 309-327.

Knopf, F.L., Johnson, R.R., Rich, T., Samson, F.B., and Szaro, R.C., 1988, Conservation of Riparian Ecosystems in the United States: The Wilson Bulletin, v. 100, no. 2, p. 272-284.

Malanson, G.P., 1993, Riparian landscapes: Cambridge, Cambridge University Press, 308 p.

Mast, J.N., and Waring, G., 1997, Dendrochronological analysis of Gooding willows in Grand Canyon National Park: Proceedings of the third biennial conference of research on the Colorado Plateau national parks, U.S. Department of Interior, Flagstaff, Ariz., p. 115-127.

McCluney, K.E., and Sabo, J.L., 2012, River drying lowers the diversity and alters the composition of an assemblage of desert riparian arthropods: Freshwater Biology, v. 57, no. 1, p. 91-103.

Melis, T.S., ed., 2011, Effects of three high-flow experiments on the Colorado River ecosystem downstream from Glen Canyon Dam, Arizona: U.S. Geological Survey Circular 1366, 147 p., http://pubs.usgs.gov/circ/1366/.

Merritt, D., and Shafroth, P., 2012, Edaphic, salinity, and stand structural trends in chronosequences of native and non-native dominated riparian forests along the Colorado River, USA: Biological Invasions, v. 14, no. 12, p. 2665-2685.

Merritt, D.M., Scott, M.L., Poff, N.L., Auble, G.T., and Lytle, D.A., 2010, Theory, methods and tools for determining environmental flows for riparian vegetation-Riparian vegetation-flow response guilds: Freshwater Biology, v. 55, no. 1, p. 206-225.

Mortenson, S., Weisberg, P., and Stevens, L., 2012, The influence of floods and precipitation on Tamarix establishment in Grand Canyon, Arizona-Consequences for flow regime restoration: Biological Invasions, v. 14, no. 5, p. 1,061-1,076.

Naiman, R.J., Decamps, H., and McClain, M.E., 2005, Riparia-Ecology, conservation, and management of streamside communities: Oxford, Elsevier Academic Press, $430 \mathrm{p}$.

Natale, E., Zalba, S.M., Oggero, A., and Reinoso, H., 2010, Establishment of Tamarix ramosissima under different conditions of salinity and water availability: Implications for its management as an invasive species: Journal of Arid Environments, v. 74, no. 11, p. 1399-1407.

NatureServe, 2012, International ecological classification standard-Terrestrial ecological classifications, vegetation associations of Grand Canyon National Park: Arlington, Va., NatureServe, $379 \mathrm{p}$.

Perry, L.G., Andersen, D.C., Reynolds, L.V., Nelson, S.M., and Shafroth, P.B., 2012, Vulnerability of riparian ecosystems to elevated $\mathrm{CO}_{2}$ and climate change in arid and semiarid western North America: Global Change Biology, v. 18, no. 3, p. 821-842. 
Poff, N.L., Olden, J.D., Merritt, D.M., and Pepin, D.M., 2007, Homogenization of regional river dynamics by dams and global biodiversity implications: Proceedings of the National Academy of Sciences, v. 104, no. 14, p. 5,732-5,737.

Porter, M.E., 2002, Riparian vegetation responses to contrasting managed flows of the Colorado River in Grand Canyon: Flagstaff, Northern Arizona University, M.S. thesis, 33 p.

Ralston, B.E., 2010, Riparian vegetation response to the March 2008 short-duration, high-flow experiment-Implications of timing and frequency of flood disturbance on nonnative plant establishment along the Colorado River below Glen Canyon Dam: U.S. Geological Survey Open-File Report 2010-1022, 30 p., http://pubs.usgs.gov/of/2010/1022/.

Ralston, B.E., Davis, P.A., Weber, R.M., and Rundall, J.M., 2008, A vegetation database for the Colorado River ecosystem from Glen Canyon Dam to the western boundary of Grand Canyon National Park, Arizona: U.S. Geological Survey Open-File Report 2008-1216, 37 p., http://pubs.usgs.gov/of/2008/1216/.

Rubin, D.M., Schmidt, J.C., and Moore, J.N., 1990, Origin, structure, and evolution of a reattachment bar, Colorado River, Grand Canyon, Arizona: Journal of Sedimentary Petrology, v. 60, no. 6, p. 982-991.

Schmidt, J.C., and Graf, J.B., 1990, Aggradation and degradation of alluvial sand deposits, 1965-1986, Colorado River, Grand Canyon National Park, Arizona: U.S. Geological Survey Professional Paper 1493, 74 p., http://pubs.er.usgs.gov/publication/pp1493.

Schmidt, J.C., and Grams, P.E., 2011, The high flows-Physical science results, in Melis, T.S., ed., Effects of three high-flow experiments on the Colorado River ecosystem downstream from Glen Canyon Dam, Arizona: U.S. Geological Survey Circular 1366, p. 53-91, http://pubs.usgs.gov/circ/1366/.

Seager, R., Ting, M., Held, I., Kushnir, Y., Lu, J., Vecchi, G., Huang, H.-P., Harnick, N., Leetmaa, A., Lua, N.-C., Li, C., Velez, J., and Naik, N., 2007, Model projections of an imminent transition to a more arid climate in southwestern North America: Science, v. 316, no. 5828, p. 1,181-1,184.

Shafroth, P.B., Stromberg, J.C., and Patten, D.T., 2002, Riparian vegetation response to altered disturbance and stress regimes: Ecological Applications, v. 12, no. 1, p. 107-123.

Shafroth, P.B., Wilcox, A.C., Lytle, D.A., Hickey, J.T., Andersen, D.C., Beauchamp, V.B., Hautzinger, A., McMullen, L.E., and Warner, A.T., 2010, Ecosystem effects of environmental flows-Modelling and experimental floods in a dryland river: Freshwater Biology, v. 55, no. 1, p. 68-85.

Sher, A.A., Marshall, D.L., and Gilbert, S.A., 2000, Competition between native Populus deltoides and invasive Tamarix ramosissima and the implications for reestablishing flooding disturbance: Society of Conservation Biology, v. 14, no. 6, p. 1,744-1,754.

Starfield, A.M., 1990, Qualitative, rule-based modeling: BioScience, v. 40, no. 8, doi: 10.2307/1311300, p. 601-604.

Stevens, L.E., Schmidt, J.C., Ayers, T.J., and Brown, B.T., 1995, Flow regulation, geomorphology, and Colorado River marsh development in the Grand Canyon, Arizona: Ecological Applications, v. 5, no. 4, p. 1,025-1,039.

Stevens, L.E., and Waring, G.L., 1986, Effects of post-dam flooding on riparian substrates, vegetation, and invertebrate populations in the Colorado River corridor in Grand Canyon, Arizona: Flagstaff, Ariz., Bureau of Reclamation, Glen Canyon Environmental Studies, contract no. IA4-AA-40-01930, GCES 19/87, 175 p. [Available from National Technical Information Service, Springfield, Va. as NTIS Report PB88-183488.] 
Stromberg, J.C., 1993, Instream flow models for mixed deciduous riparian vegetation within a semiarid region-Regulated Rivers: Research \& Management, v. 8, no. 3, p. 225-235.

Stromberg, J., 1998, Dynamics of Fremont cottonwood (Populus fremontii) and salt cedar (Tamarix chinensis) populations along the San Pedro River, Arizona: Journal of Arid Environments, v. 40, no. 2, p. 133-155.

Topping, D.J., Rubin, D.M., and Vierra, L.E., Jr., 2000, Colorado River sediment transport 1-Natural sediment supply limitation and the influence of the Glen Canyon Dam: Water Resources Research, v. 36 , no. 2 , p. 515-542

Topping, D.J., Schmidt, J.C., and Vierra, L.E., 2003, Computation and analysis of the instantaneousdischarge record for the Colorado River at Lees Ferry, Arizona-May 8, 1921, through September 30, 2000: U.S. Geological Survey Professional Paper 1677, 118 p., http://pubs.usgs.gov/pp/pp1677/.

Turner, R.M., and Karpiscak, M.M., 1980, Recent vegetation changes along the Colorado River between Glen Canyon Dam and Lake Mead, Arizona: U.S. Geological Survey Professional Paper 1132, 125 p., http://pubs.er.usgs.gov/publication/pp1132.

U.S. Department of the Interior, 1996, Glen Canyon Dam beach/habitat building flow-Final environmental assessment and finding of no significant impact: Salt Lake City, Utah, Bureau of Reclamation, Upper Colorado Region, 68 p. + attachments.

U.S. National Vegetation Classification, 2014, Your guide to inventorying natural and cultural plant communities: Website, accessed February 14, 2014, at http://usnvc.org/.

Waring, G.L., 1995, Current and historical riparian vegetation trends in Grand Canyon, using multitemporal remote sensing analyses of GIS sites-Final report: National Park Service, submitted to Bureau of Reclamation, Glen Canyon Environmental Studies, and Northern Arizona University, cooperative agreement no. CA 8000-8-0002, 20 p.

Webb, R.H., and Griffith, P.G., 2001, Monitoring of coarse sediment inputs to the Colorado River in Grand Canyon: U.S. Geological Survey Fact Sheet 019-01, 4 p., http://pubs.usgs.gov/fs/FS-019-01/.

Wondzell, S.M., Hemstrom, M.A., and Bisson, P.A., 2007, Simulating riparian vegetation and aquatic habitat dynamics in response to natural and anthropogenic disturbance regimes in the Upper Grande Ronde River, Oregon, USA: Landscape and Urban Planning, v. 80, no. 3, p. 249-267.

Zweig, C.L., and Kitchens, W.M., 2009, Multi-state succession in wetlands-A novel use of state and transition models: Ecology, v. 90, no. 7, p. 1,900-1,909. 